\title{
THE RULE OF LAW AND LEGAL-PROCESS REASONS IN ATTORNEY ADVISING
}

\author{
W. Bradley Wendel ${ }^{*}$ \\ INTRODUCTION
}

The political and moral ideal of the rule of law refers to a disciplined practice of giving particular types of reasons. The law is a means of governing a political community comprised of free and equal citizens who are capable of self-governance. To be effective as law, law must be capable of being communicated and grasped by its subjects, of being understood and applied in line with its intended meaning. Understanding the meaning of law depends, in turn, on grasping its social and normative dimensions. Giving a legal justification necessarily means committing oneself to a practical stance toward the law that assumes one's membership in a political community and accepts the community's laws as reasons for action. ${ }^{1}$ Reasons are what make any action of a rational agent intelligible; legal reasons are what make an action intelligible as something publicly authorized, with appropriate reference to the procedures and norms of a political system that is established to regulate the interactions among free and equal citizens in circumstances of pluralism and disagreement.

Ordinarily we think of courts as the most important interpreters and administrators of law. The emphasis on courts makes perfect sense in the context of litigation, where all the adversary parties are capable, at least in principle, of making their strongest argument on the law and facts. It is then for the court to decide what rights and remedies the parties ought to have

\footnotetext{
* Professor of Law, Cornell University. This paper was presented as a faculty workshop at the University of Virginia Law School, and earlier versions were presented at the Fourth Legal Ethics Schmooze at UCLA Law School and as a lecture in the Program on Politics, Law, and Social Thought at Rice University. I am grateful to all the participants in all of these programs who provided helpful comments, and benefitted particularly from spirited discussions with Charles Barzun and Gregg Strauss.

${ }^{1}$ The position taken here is plainly indebted to H.L.A. Hart's idea of the internal point of view (IPOV). See H.L.A. HART, THE CONCEPT OF LAW 56-57, 88-89 (2d ed. 1994). For an exceptionally insightful exploration of the role of the IPOV in Hart's system and legal philosophy generally, see Gerald J. Postema, Legal Philosophy IN THE TWENTIETH Century: THe COMmon LAW World § 7.3.2, at 291-99 (2011). See also Jeffrey Kaplan, Attitude and the Normativity of Law, 36 L. \& PHIL. 469 (2017). This Article differs from the usual IPOV literature in asking explicitly whether one ought to take the IPOV. This is a normative question within political ethics, not a conceptual issue about the nature of law, as Hart understood the IPOV.
} 
against each other. But vast arenas of activity by lawyers are connected with litigation in only the most attenuated way. Transactional and advising practice takes place "in the shadow of the law," ${ }^{2}$ to be sure, but the overwhelming majority of legal issues connected with a particular transaction or action by the client will never be litigated. It is in precisely these situations, however, when a client comes to a lawyer and asks, “Can I do this?”, that the law or the legal system must be capable of providing guidance. And in these contexts, the action-guiding function of law necessarily depends on its application by lawyers to their clients' situations. Moreover, legality as a mode of governance depends on good faith application of law by lawyers. ${ }^{3}$

Traditionally the obligation of good faith application and interpretation has been an aspect of a professional ideal that recognizes the separation between law and morality but nevertheless instructs lawyers to advise clients based on moral considerations, the public interest, or the common good as well as the content of positive law. For example, former Watergate Special Prosecutor Archibald Cox suggested that one of the ethical obligations of lawyers serving as advisors to powerful clients is to say: "Yes, the law lets you do that, but don't do it. It is a rotten thing to do." ${ }^{4}$ Legal historian Lawrence Friedman contends that lawyers always served first themselves, then their clients, and last "their conception of that diffuse, nebulous thing, the public interest." ${ }^{5}$ But rhetorically at least, bar leaders have consistently maintained, in the words of Elihu Root, that "[a]bout half the practice of a decent lawyer consists in telling would-be clients they are damned fools and should stop."6 Today many scholars contend that the professional ideal still has force. Former Yale Law School dean Anthony Kronman, for example, maintains that "law is a public calling which entails a duty to serve the good of the community as a whole, and not just one's own good or that of one's clients."7 Traditional professionalism responds to the limitations of coercive legal sanctions as a means of securing social order and stability by investing

2 See Robert H. Mnookin \& Lewis Kornhauser, Bargaining in the Shadow of the Law: The Case of Divorce, 88 YALE L.J. 950 (1979) (arguing that even private ordering is accomplished with formal law in the background).

${ }^{3}$ For a similar exploration of the application of law in good faith by judges, see STEVEN J. BurTON, JudGing IN GOOD FAITH (1992). A recent effort in the same general direction, focusing on law-application by lawyers, but more doctrinally focused, is Samuel F. Buell, Good Faith and Law Evasion, 58 UCLA L. REV. 611 (2011).

${ }^{4}$ Quoted in MARY ANN GLENDON, A NATION UNDER LAWYERS 35 (1994).

${ }^{5}$ LAWRENCE M. FriedMAN, A HiSTORY OF AMERICAN LAW 639 (1985).

6 Gerald W. Gawalt, The New High Priests: Lawyers in Post-Civil War AMERICA 4 (1984).

${ }^{7}$ Anthony T. Kronman, The Law as a Profession, in ETHICS IN PRACTICE: LAWYERS' Roles, Responsibilities, AND REgulation 31 (Deborah L. Rhode, ed., 2000). 
lawyers with "quasi-public responsibility for honest observance of the basic rules and procedures of the framework." 8

Today the dominant way of thinking about lawyers is as providers of something called "legal services." This manner of speaking obscures a subtle but central issue in both the theory of professional ethics and jurisprudence. That question is whether lawyers provide only information and technical expertise, or whether there is a thicker conception of professionalism that is bound up with the exercise of judgment about morality, relational interests, the public good, or the substance beyond the form (or the spirit beyond the letter) of the law. The differentiation of the spheres of market and the state leaves ambiguous the location of the legal profession on either side of that dividing line. Are lawyers merely economic actors, or are they bound up somehow with the practice of governance?

This Article locates lawyers on the governance side of the dividing line. It argues for a version of the traditional professional ideal, emphasizing the way lawyers mediate between citizens and the state, but with two important differences. First, legal advising is not oriented toward the common good or the public interest, but at the substantive content of a community's law. In jurisprudential terms it belongs to the positivist family of theories about the nature of law. The idea of interpreting and applying the law in good faith does not transform it into a kind of covert natural law account, and the normative force of law is not dependent upon there being moral reasons to do what the law requires. Second, the focus is not on arriving at some mythical "right

${ }^{8}$ Robert W. Gordon \& William H. Simon, The Redemption of Professionalism?, in ROBERT L. NELSON, ET AL., EDS., LAWYERS' IDEALS/LAWYERS' PRACTICES: TrANSFORMATIONS IN THE AMERICAN LEGAL PROFESSION 230, 235 (1992).

${ }^{9}$ See, e.g., Gillian K. Hadfield, Legal Infrastructure and the New Economy, 8 I/S: A JOURNAL OF LAW AND POLICY FOR THE INFORMATION SOCIETY 1 (2012). Hadfield describes law functionally, as contributing toward private ordering in a market economy:

[W] can think of law as a supply of relational services-economic inputs that produce value by helping to structure and regulate relationships among economic actors and between economic actors and communities. . . . The economic demand for law is thus a demand for legal inputs that will support the creation of value in economic relationships.

Id. at 10. Hadfield's account is considerably richer than that given by some neo-classical law and economics scholars, who understand the law is nothing more than a constraint on the utility maximization of clients, who take the expected disutility of legal sanctions into account when deciding how to act. See, e.g., Steven Shavell, Legal Advice About Contemplated Acts: The Decision to Obtain Advice, Its Social Desirability, and Protection of Confidentiality, 17 J. LEG. STUD. 123 (1988). For Hadfield, law is a resource, related to social and relational capital, and norms of trust and reciprocity. 
answer" to a question of law, ${ }^{10}$ but on giving appropriate types of reasons in justification for a conclusion of law. In political-moral terms, legal advising is about reason-giving, not hitting the target. When lawyers provide legal advice, they are thereby expressing commitment to a specific pattern of justification, in reliance on particular types of considerations. ${ }^{11}$ The position defended here harks back to a core insight of the legal process school of the mid-Twentieth Century. Legal-process theorists emphasized the connection between the rule of law, the dignity and moral agency of citizens, and the formal requirement of providing a reasoned elaboration for official decisions. ${ }^{12}$ Legal argumentation, as a discursive practice, must ultimately be grounded in considerations of public reason - that is, the reasons that individuals would offer to others they recognize as free and equal citizens of a political community. The process of reason-giving answering to the ideal of the rule of law will establish both the normativity of law and a sufficient degree of determinacy to enable it to perform its function of governing a political community in circumstances of pluralism and disagreement.

This Article aims to connect jurisprudential scholarship on the nature and value of law with the perennial question of what practical stance a lawyer ought to adopt with respect to the law, when advising a client. As Richard Posner has stated, with his typical snarkiness, "[O]ne would like [philosophical analysis] to have some pay-off; something ought to turn on the answer to the question 'What is law?' if the question is to be worth asking by

10 See Brian Bix, Ronald Dworkin's Right Answer Thesis, in LAw, LANGUAGE, AND LEgAl DeterminAcy (Brian Bix ed. 1995) (evaluating Dworkin's claim that there is a unique right answer to most questions of law). The position here attempts to sidestep the radical critique of liberalism, associated with scholars like Duncan Kennedy and Roberto Unger, which argues that the exercise of legal authority is not legitimate unless the law is capable of determining a unique answer to a question arising under the law. See Christopher L. Kutz, Just Disagreement: Indeterminacy and Rationality in the Rule of Law, 103 YALE L.J. 994 (1994) (providing an overview of the skeptical challenge to legal liberalism).

${ }^{11}$ See Kevin Toh, Hart's Expressivism and His Benthamite Project, 11 LEG. THEORY 75 (2005).

12 See Postema, supra note __, at 135 (discussing Karl Llewellyn and Edward Levi); Henry M. HART, JR. \& Albert M. SACKs, The Legal Process: BASIC Problems in the MAKING AND APPLICATION OF LAW (William N. Eskridge, Jr. \& Philip P. Frickey eds., 1994); EDWARD H. LEVI, AN INTRODUCTION TO LEGAL REASONING (1949); NEIL DUXBURY, PATTERNS OF AMERICAN JURISPRUDENCE 205-32 (1995) (explaining that legal process theorists aimed at elaborating the reason embodied in the fabric of the law itself); see also Geoffrey C. Shaw, H.L.A. Hart's Lost Essay: Discretion and the Legal Process School, 127 HARV. L. REV. 666 (2013) (discussing some of the connection to be explored here, between Hart's legal positivism and the legal process school). For my early attempt at beginning this project on legal-process legal ethics, see W. Bradley Wendel, The Limits of Positivist Legal Ethics: A Brief History, a Critique, and a Return to Foundations, 30 CAN. J. L. \& JURIS. 443(2017). 
people who could use their time in other socially valuable ways." 13 I'm not sure if I could use my time in other socially valuable ways, but I do want to challenge Posner's framing of these questions by focusing on the professional obligations of lawyers when seeking to understand the social value of law and legality. This Article seeks to understand how legality affects the practical reasoning of citizens subject to it, with the assumption that they will be assisted by expert legal advisors. The first step in this practical reasoningbased account of legal advising is to recognize citizens as free and equal, responsible agents, with the capacity to respond to reasons:

[Legal systems] operate by using, rather than suppressing and shortcircuiting, the responsible agency of ordinary human individuals. ... The publicity and generality of law look to what Henry Hart and Albert Sacks called 'self-application,' that is, to people's capacities for practical understanding, for self-control, and for the self-monitoring and modulation of their own behavior, in relation to norms that they can grasp and understand. ${ }^{14}$

It follows, then, that lawyers must be prepared to offer arguments that can be assessed for their soundness and accepted as reason-giving by other rational agents. Moreover, because arguments offered in justification of a conclusion of law are necessarily bound up with a political community's norms for the conduct of citizens, the reasons offered must be aimed at a reconstruction of the community's position on a matter:

[T]here is a difference between trying to game and manipulate a system as a resistance movement or alienated outsider would, and to engage in a committed and good faith struggle within the system to influence it to fulfill what a good faith interpreter would construe as its best values and purposes. $^{15}$

Finally, a lawyer's position with respect to a legal issue can accordingly be evaluated as more or less reasonable, even though it may not be possible to say it represents the unique right answer to the question. Constraints on the presentation of arguments by lawyers are provided by the political value of the rule of law, related to a disciplined practice of reason-giving, which in turn responds to the dignity and equality of members of a political community. This account provides a distinctive critical standpoint from

\footnotetext{
${ }^{13}$ Richard A. Posner, LAW AND LEgAL THEORY In ENGLAND AND AMERICA 3 (1996).

14 Jeremy Waldron, The Concept and the Rule of Law, 43 GA. L. REV. 1, 26-27 (2008).

${ }^{15}$ Robert W. Gordon, A New Role for Lawyers?: The Corporate Counselor After Enron, 35 CONN. L. REV. 1185, 1200 (2003).
} 
which to evaluate legal argument, but it should not be misunderstood as a method or touchstone for determining when a legal justification hits the target. There may be a range of incompatible but reasonable positions, each of which is defensible as lawful.

Section I describes the sort of cases I am interested in - not lawyer participation in clear illegality (where the question one might ask is "what were they thinking?"), but lawyers assisting clients in conduct that at least passes a straight-face test for compliance with formal legal requirements, but otherwise appears to be unethical, anti-social, or inconsistent with what appears to be the spirit or purpose of the law. Section II considers the two predominant professional responses. The first, described in a decline-and-fall narrative in Section II.A, is the traditional ideal of professionalism, under which a lawyer ought not to help a client do something that the lawyer believes is a rotten thing to do. The second response, considered in Section II.B, has two variations. One is the position, associated with O.W. Holmes, Jr., that a sufficient condition for the permissibility of professional legal advice is the lawyer's conclusion that the client either will not be detected and punished, or that the client is willing to pay whatever penalty is imposed. The other variation is a bit less aggressive, but still maintains that a lawyer should provide whatever lawful assistance the client requests, where "lawful" is defined to permit conduct that is not clearly prohibited by existing law. Section III sets out the positive claim defended in this Article. Section III.A elaborates on the relationship between rational agency, public reason, and the rule of law. Section III.B fleshes out a model of legal advising informed by the political and moral value of the rule of law, and considers some alternative recently proposed under which law and morality are viewed as a single domain of practical reasoning. Finally, Section IV briefly considers some objections that have been raised against legal process theorizing in general, and as applied in this account.

\section{A Typology of UnETHICAL LEGAL ADVISING.}

There are two types of legal ethics scandals. The first is the most common, but raises few theoretically interesting issues. It involves conduct that, upon careful consideration by a trier of fact in a judicial proceeding or an independent investigator, is plainly unlawful. The nature of the wrongdoing in these cases is clear, at least to all but the most partisan observers. Scandals of this type raise institutional issues, such as how to design procedures and policies to prevent rogue partners from engaging in illegal conduct that threatens a law firm with massive exposure to liability. They also may raise fascinating questions pertaining to cognitive and organizational psychology, 
such as how it is possible for ordinarily good, well-meaning people to slip gradually into a pattern of serious lawbreaking. ${ }^{16}$ An example of this type of case would be the so-called robo-signing scandal in which, among other misconduct, bank lawyers signed complaints seeking mortgage foreclosures, including affidavits which stated that bank employees had reviewed the underlying documents, when in fact they had not. ${ }^{17}$ The practices resulted in a total $\$ 9.3$ billion settlement, paid by Bank of America, Wells Fargo, and other large financial institutions. Similarly, the participation by lawyers in fraudulent transactions at issue in the recent Refco litigation was unquestionably wrongful (the lead lawyer on the representation was convicted of federal criminal charges and sentenced to prison). ${ }^{18}$ Cases like this are not occasions for thinking systematically about the role of lawyers and what they are ethically permitted or obligated to do. No one seriously questions that, along with serving as agents of clients, with duties of loyalty and confidentiality, lawyers have a duty not to counsel or assist their clients in conduct that is a violation of law.

Far more interesting are cases in which lawyers are subjected to public criticism, but it is unclear either whether their participation was wrongful at all or, if one argues it was wrongful, the reason why is contestable. These

${ }^{16}$ See, e.g., Jennifer K. Robbennolt \& Jean R. Sternlight, Behavioral Legal Ethics, 45 ARIZ. ST. L.J. 1107 (2013); Andrew M. Perlman, Unethical Obedience by Subordinate Attorneys: Lessons from Social Psychology, 36 Hofstra L. REv. 451 (2007); John M. Darley, The Cognitive and Social Psychology of Contagious Organizational Corruption, 70 BROOK. L. ReV. 1177 (2005); Kimberly Kirkland, Ethics in Large Law Firms: The Principle of Pragmatism, 35 U. Mem. L. Rev. 631 (2005); Donald C. Langevoort, The Organizational Psychology of Hyper-Competition: Corporate Irresponsibility and the Lessons of Enron, 70 GEO. WASH. L. REV. 968 (2002); John M. Darley, How Organizations Socialize Individuals into Evildoing, in CODES OF CONDUCT: BEHAVIORAL RESEARCH INTO BUSINESS ETHICS 13 (David M. Messick \& Ann E. Tenbrunsel eds., 1996); Donald C. Langevoort, Where Were the Lawyers? A Behavioral Inquiry Into Lawyers' Responsibility for Clients' Fraud, 46 VAND. L. REV. 75 (1993).

${ }^{17}$ See, e.g., Elizabeth Shell, The Road to "Robo-Signing," PBS NewsHOUR (Oct. 18, 2010), available at http://www.pbs.org/newshour/rundown/faulty-paperwork-lendinginstitutions-have/

${ }^{18}$ See In re Refco, Inc., Securities Litig., 609 F. Supp. 2d 304 (S.D.N.Y. 2009), aff'd sub nom. Pacific Inv. Mgmt. Co. LLC v. Mayer Brown LLP, 603 F.3d 144 (2d Cir. 2010); Thomas H. Lee Equity Fund V, L.P. v. Mayer Brown, Rowe \& Maw, LLP, 612 F. Supp. 2d 267 (S.D.N.Y. 2009). The cases involved a scheme by a brokerage firm to conceal losses by setting up a series of round-trip trades that temporarily transferred ownership of uncollectable receivables from the firm to purportedly independent parties. Mayer Brown provided advice on the structure and terms of the transactions, negotiated with third parties, and drafted the necessary documents. Joseph Collins, the engagement partner at Mayer Brown on the Refco matter, was convicted of conspiracy, securities fraud, and wire fraud. See Patricia Hurtado, Ex-Refco Lawyer Gets Year for Aiding \$2.4 Billion Fraud, Bloomberg News (July 15, 2013). 
cases tend to involve conduct by clients that, while not strictly against the law, is nevertheless law-evading, carefully designed to work around legal prohibitions, abusive, or otherwise contrary to the interests of society. At the very least, one can imagine a straight-faced argument that the client's actions comply with formal legal requirements. Creativity and problem-solving are important professional skills, and in many cases there is nothing wrong with finding a way to help a client accomplish its objectives while staying within the letter of the law. To borrow from the analysis of tax law, there is a difference between legitimately minimizing one's legal liability and the illegitimate evasion of law. ${ }^{19}$ However, it has been well understood since the American Legal Realist movement in the 1920's that law is either moderately or radically indeterminate, so that a lawyer applying the law to a client's case can justify a wide range of outcomes. ${ }^{20} \mathrm{~A}$ different strand of realism challenges not the determinacy of law but its normativity, implying that a lawyer may regard the law as nothing more than an obstacle to engineer around, as opposed to a source of reasons bearing on what the client ought to do. ${ }^{21}$ The intellectually significant lawyer-advising scandals raise questions about the reason-giving force of law and, concomitantly, about the source and nature of any constraints that ought to be recognized in the way in which the law is interpreted and applied by lawyers.

Some instances of the second, interesting, type of scandal include the following:

The Rosenstein Memo. In May 2017, President Trump fired F.B.I. Director James B. Comey, who was heading an investigation into allegations that Russian intelligence services had collaborated with individuals associated with the Trump campaign to influence the outcome of the 2016 presidential election. ${ }^{22}$ When Trump fired Comey, he initially stated that he

\footnotetext{
${ }^{19}$ See, e.g., TANina Rostain \& Milton C. REGAN, JR., CONFIDENCE GAMES: LAWYERS, AcCountants, AND THE TAX Shelter Industry 25-35 (2014); Philip A. Curry, Claire A. Hill \& Francesco Parisi, Creating Failures in the Market for Tax Planning, 26 VA. TAX REV. 943 (2007); Michael L. Schler, Ten More Truths About Tax Shelters: The Problem, Possible Solutions, and a Reply to Professor Weisbach, 55 TAX L. REV. 325 (2002).

${ }^{20}$ See, e.g., Brian Leiter, Legal Formalism and Legal Realism: What Is the Issue?, 16 LEG. THEORY 111 (2010); Christian Zapf \& Eben Moglen, Linguistic Indeterminacy and the Rule of Law: On the Perils of Misunderstanding Wittgenstein, 84 GEO. L.J. 485 (1996); Jeremy Waldron, Vagueness in Law and Language: Some Philosophical Issues, 82 CAL L. REV. 509 (1994); Lawrence B. Solum, On the Indeterminacy Crisis: Critiquing Critical Dogma, 54 U. CHI. L. REV. 462 (1987); Sanford Levinson, Frivolous Cases: Do Lawyers Really Know Anything At All?, 24 OsGOODE HALL L.J. 355 (1986).

${ }^{21}$ See infra notes __ _ _ and accompanying text.

${ }^{22}$ See, e.g., Michael D. Shear \& Matt Apuzzo, F.B.I. Director James Comey Is Fired by Trump, N.Y. TIMES (May 9, 2017).
} 
was doing so based on the advice of recently confirmed Deputy Attorney General Rod J. Rosenstein. ${ }^{23}$ The Rosenstein letter focused on Trump's alleged dissatisfaction with the way Comey had handled the investigation of Hillary Clinton's email handling practices. Trump subsequently offered a completely different explanation, telling Lester Holt of NBC News that he would have fired Comey regardless of what advice Rosenstein had given him. ${ }^{24}$ Rosenstein was criticized providing a bogus legal opinion, which served as "window dressing on a pre-cooked political decision" for which the President wanted "the patina of a high-minded rationale." 25 The criticism of Rosenstein presupposes a very different view of legal advising, in which the lawfulness of a proposed course of action should make a difference, both to the client and to the client's advisor. To merely provide "string of quotations, plucked out of context and clipped together for rhetorical effect" 26 is to make a mockery of what should be a disciplined process of giving principled reasons for and against the client's desired action. On the other hand, one might argue that if Trump in fact had the legal right to fire Comey, what difference does it make that Rosenstein provided legal cover?

The Panama Papers. In the spring of 2016, an ad hoc international working group of investigative journalists, led by the German newspaper Süddeutsche Zeitung, published an analysis of a massive document leak from a Panamanian law firm called Mossack Fonseca, obtained from a whistleblower inside the firm. ${ }^{27}$ The leaked records detailed how wealthy businesspeople and government officials in countries including Iceland, China, Russia, Brazil, and Saudi Arabia used complex structures involving offshore shell corporations to hide their true identity as owners of assets. Wile the firm claimed to be in compliance with Panamanian law, its founders were taken into custody in Panama in February 2017 on charges of money

${ }^{23}$ See, e.g., Jenna Johnson, After Trump Fired Comey, White House Staff Scrambled to Explain Why, WASH. POST (May 10, 2017).

${ }^{24}$ See Peter Baker \& Michael D. Shear, Trump Shifts Rationale for Firing Comey, Calling Him a "Showboat", N.Y. Times (May 11, 2017) (Trump stating, "when I decided to just do it, I said to myself, I said, 'You know, this Russia thing with Trump and Russia is a made-up story.”).

${ }^{25}$ Benjamin Wittes, Et Tu Rod? Why The Deputy Attorney General Must Resign, LAWFARE (May 12, 2017). For the relationship between Wittes and Comey, see Benjamin Wittes, What James Comey Told Me About Donald Trump, LAWFARE (May 18, 2017). 2017).

${ }^{26}$ Daphna Renan \& David Pozen, Rod Rosenstein Pulls a Comey, LAWfARE (May 11,

${ }^{27}$ See International Consortium of Investigative Journalists, Giant Leak of Offshore Financial Records Exposes Global Array of Crime and Corruption, ICIJ: THE PANAMA PAPERS (Apr. 3, 2016), https://panamapapers.icij.org/20160403-panama-papers-globaloverview.html. See also Eric Lipton \& Julie Cresswell, Panama Papers Show How Rich United States Clients Hid Millions Abroad, N.Y. TimES (June. 5, 2016). 
laundering. ${ }^{28}$ The firm had offices in many countries and in Nevada and Wyoming in the United States, ${ }^{29}$ and reportedly worked with prominent multinational banks. ${ }^{30}$ Where there are banks, there are lawyers. Although the extent of involvement of lawyers not affiliated with the Mossack Fonseca firm has yet to be revealed, it is all but certain that lawyers have been involved in transactions with offshore shell corporations. These transactions may have been used to hide assets from creditors or tax authorities, or to conceal funds received from illicit activities.

For example, an article in the New York Times describes the case of William Ponsoldt, who moved \$134 million through banks in six countries, sheltering his fortune from income, and estate and gift taxation, and transferring it to his children. ${ }^{31} \mathrm{~A}$ crucial step in the transaction was the creation of a Panamanian foundation which, under applicable domestic law need not actually be dedicated to any charitable purpose, and can be used to designate family members as beneficiaries of assets "donated" to the foundation. The transaction appeared to be "carefully crafted to help its clients evade United States tax laws." ${ }^{32}$ The foundation was controlled by "nominee directors," who were in fact employees of the law firm. Once the foundation was created, the law firm explained, it became a "black hole" into which assets could be made to disappear. ${ }^{33}$ Cases like this are analytically difficult because they involve highly technical areas of law in which it is possible to manipulate legal formalities to accomplish purposes that could be characterized as anti-social or not in the public interest. Are the lawyers who represented Ponsoldt and numerous other wealthy individuals subject to

${ }^{28}$ See Will Fitzgibbon, Emilia Díaz-Struck and Michael Hudson, Founders of Panama Papers Law Firm Arrested on Money Laundering Charges, ICIJ: THE PANAMA PAPERS (Feb. 11, 2017), https://panamapapers.icij.org/20170211-mossfon-panama-arrests.html.

${ }^{29}$ See Kevin G. Hall \& Marissa Taylor, US Scolds Others About Offshores, But Looks Other Way at Home, MCCLATCHY NEWSPAPERS (Apr. 5, 2016), http://www.mcclatchydc.com/news/nation-world/national/article70008302.html.

McClatchy is the U.S. member of the international consortium. In response to the McClatchy report, the Wyoming Secretary of State investigated and penalized the state office of Mossack Fonseca for failure to comply with statutory requirements concerning registered agents of corporations. Kevin G. Hall, Wyoming Investigates Panama Papers Law Firm, MCCLATCHY NEWSPAPERS (Apr. 6, 2016), http://www.mcclatchydc.com/news/nationworld/national/article70408322.html.

${ }^{30}$ See Martha M. Hamilton and Hamish Boland-Rudder, Banks Ordered to Provide Info on Panama Dealings to NY Regulator, ICIJ: THE PANAMA PAPERS (Apr. 20, 2016), https://panamapapers.icij.org/20160420-ny-banks-regulator.html.

31 See Eric Lipton \& Julie Creswell, Panama Papers Show How Rich United States Clients Hid Millions Abroad, N.Y. TimES (June 5, 2016).

${ }^{32} \mathrm{Id}$.

${ }^{33} I d$. 
criticism for structuring transactions that comply with applicable law (assuming they do)?

Enron-Type Shenanigans. One of the highest-profile legal advising scandals of the last two decades was the collapse of formerly high-flying Enron corporation after revelation of accounting irregularities that allowed the corporation to hide hundreds of millions of dollars of debt using offbalance-sheet entities secretly controlled by Enron officers. ${ }^{34}$ What makes the case interesting from the point of view of a theory of legal advising is that the lawyers set out to comply with the law when they designed the transactions. It was the attitude toward the law expressed by lawyers that was so remarkable. The conduct of professionals - both accountants and lawyers in the Enron transactions was brilliantly characterized in this way:

Say you have a dog, but you need to create a duck on the financial statements. Fortunately, there are specific accounting rules for what constitutes a duck: yellow feet, white covering, orange beak. So you take the dog and paint its feet yellow and its fur white and you paste an orange plastic beak on its nose, and then you say to your accountants, "This is a duck! Don’t you agree that it's a duck?” And the accountants say, "Yes, according to the rules, this is a duck." Everybody knows that it's a dog, not a duck, but that doesn't matter, because you've met the rules for calling it a duck. ${ }^{35}$

The image of the dummied-up duck suggests a distinction between "what the rules require" and a more substantive, purposivist, or common-sensical evaluative standpoint.

But it is far from self-evident in the law that complying with the form of duck-creating rules is insufficient to make something a duck. In Gregory v. Helvering the Supreme Court established that the IRS may base the tax treatment of a transaction on its economic substance, rather than its form. ${ }^{36}$ Gregory is the starting point for the analysis of anti-avoidance rules in U.S. tax law. Although there are numerous common law and statutory antiavoidance rules, they all share the common feature of looking to the business

\footnotetext{
${ }^{34}$ See, e.g., Susan Koniak, When the Hurly Burly's Done: The Bar's Struggle with the S.E.C., 103 Colum. L. REV. 1236 (2004); Roger C. Cramton, Enron and the Corporate Lawyer: A Primer on Legal and Ethical Issues, 58 BUS. LAW. 143 (2002). For details on the transactions and the law firm's role see In re Enron Corp. Securities Litig., 235 F. Supp. 2d 549 (S.D. Tex. 2002).

${ }^{35}$ Quoted in Bethany McLean \& Peter ElKind, The SMartest GuYs in the RoOM: THE AMAZING RISE AND SCANDALOUS FALL OF ENRON 142-43 (2003).

36293 U.S. 465 (1935).
} 
purpose or economic substance of a transaction as a check on the legitimacy of the taxpayer's position. ${ }^{37}$ Anti-avoidance rules are notoriously difficult to apply, because courts continue to treat some tax-motivated transactions as having a sufficient business purpose to sustain the taxpayer's position. ${ }^{38}$ Distinguishing between what might be called "real business transactions done in a funny way" 39 and an impermissible tax shelter is difficult due to the

${ }^{37}$ For example, in ACM Partnership v. Commissioner, 157 F.3d 231 (3d Cir. 1998), an installment sale transaction was designed in such a way that the gain portion of the transaction occurred in the first year, during which most of the gain was allocated to a nonU.S. taxpayer, a Dutch bank. Because the partnership interest of the non-U.S. taxpayer had been redeemed after the first year, the following years' losses were allocated to a U.S. taxpayer, a corporation seeking to shelter a capital gain. The Third Circuit affirmed the Tax Court's disallowance of the taxpayer's position, holding that the proper inquiry should be into the objective economic reality of the transaction, not the taxpayer's motive. The corporation claimed that the transaction was either a hedge or a means to repurchase debt in a confidential manner, but the court rejected these characterizations in light of the significant difference in transaction costs between the installment sale and other means that were available to accomplish the economic purposes of hedging or debt repurchase.

${ }^{38}$ See, e.g., United Parcel Service v. Commissioner, 254 F.3d 1014 (11th Cir. 2001). UPS created a separate entity in Bermuda to receive income from excess valuation charges paid by customers to insure shipments on UPS. Profit from these excess valuation charges is thus sheltered from U.S. taxation. The Commissioner pointed out that, after the transaction, UPS continued to do exactly what it had always done before the transaction, namely collect what amount to payments by customers to insure their shipments and provide insurance coverage in the event of loss; the only difference is that the revenue from these charges now went to a formally separate entity in Bermuda. The court emphasized the principles that tax planning is permissible and that economically similar behavior may be treated differently for tax purposes.

For instance, two ways to infuse capital into a corporation, borrowing and sale of equity, have different tax consequences; interest is usually deductible and distributions to equityholders are not. There may be no tax-independent reason for a taxpayer to choose between these different ways of financing the business, but it does not mean that the taxpayer lacks a "business purpose.”' To conclude otherwise would prohibit taxplanning.

Id. at 1019. The court failed, in my judgment, to articulate a tax-independent reason for choosing to route the stream of income from excess-value charges through Bermuda. It is difficult to see how the establishment of the Bermuda subsidiary was any more economically substantial than the installment sale in ACM. See supra note

39 See Michael L. Schler, Ten More Truths About Tax Shelters: The Problem, Possible Solutions, and a Reply to Professor Weisbach, 55 TAX L. REV. 325, 337 (2002). Although speaking in general terms one can say that it is difficult to differentiate "real business done in a funny way" from illegal tax evasion, there is a difference, and lawyers who assist clients in fraudulent transactions may be criminally liable. Three lawyers at the Dallas law firm Jenkens \& Gilchrist were indicted for assisting clients in the structuring of fraudulent tax shelters. See Lynnley Browning, Seven Indicted on Charges of Selling Tax Shelters, N.Y. TIMES (Jun. 10, 2009), at B1. 
inherent artificiality of taxation and an unclear boundary beyond which formal features of a transaction can no longer be relied upon. ${ }^{40}$

The Torture Memos. The story of the George W. Bush administration's response to the September 11, 2001, terrorist attacks is well known. ${ }^{41}$ Lawyers within the administration were called upon to provide advice on the legality of policies regarding the detainment and interrogation of individuals picked up in Afghanistan, Pakistan, and elsewhere and suspect of involvement in the attacks. The Office of Professional Responsibility (“OPR") within the Justice Department found that two lawyers in the Office of Legal Counsel, John Yoo and Jay Bybee, had engaged in professional misconduct by failing to provide "thorough, candid, and objective" legal analysis. $^{42}$ The lawyers' most notorious advice was contained in a memo dealing with the legality of interrogation techniques to be used on suspected al-Qaeda operatives. ${ }^{43}$ Interestingly, the OPR's Report did not fault the lawyers for reaching the wrong conclusions of law, but of failing to respect procedural norms of sound, good-faith legal advising. For example, some of Yoo’s legal research seemed sloppy. ${ }^{44}$ The lawyers' work product failed to

${ }^{40}$ See Cottage Savings Association v. Commissioner, 499 U.S. 554 (1991) (concluding that economically identical interests could be treated as materially different for tax purposes, where the taxpayer gave up legal entitlements different from those which it received).

${ }^{41}$ See, e.g., HAROLD H. BRUfF, BAD ADVICE: BuSH's LAWYERS IN THE WAR ON TERROR (2009); JANE MAYER, THE DARK SIDE: THE INSIDE STORY OF HOW THE WAR ON TERROR Turned INTO A War on AMERICAN IdEAls (2008); PhilipPE SANDS, The TORTuRE TEAM: RUMSFELD's MEMO AND THE BETRAYAL OF AMERICAN VALUES (2008); JACK GOLDSMITH, THE TERROR PRESIDENCY: LAW AND JUDGMENT INSIDE THE BUSH ADMINISTRATION (2007); Jens D. Ohlin, The Torture Lawyers, 51 HARV. InT'L L.J. (2010); W. Bradley Wendel, F.W. Wickwire Lecture: Executive Branch Lawyers in a Time of Terror, 31 DALHOUSIE L.J. 247 (2009); David Luban, The Torture Lawyers of Washington, in LEGAL ETHICS AND HUMAN DiGNITY (2007).

42 See Department of Justice, OfFice of Professional Responsibility, RePort: INVESTIGATION INTO THE OFFICE OF LEGAL COUNSEL'S MEMORANDA CONCERNING ISSUES RELATING TO THE CENTRAL INTELLIGENCE AGENCY'S USE OF “ENHANCED INTERROGATION TECHNIQUES” ON SUSPECTED TERRORISTS (July 29, 2009) [hereinafter “OPR REPORT”]. For a discussion of the subsequent history of the OPR Report and a critique of the reversal, by Associate Deputy Attorney General David Margolis, of the OPR's findings, see W. Bradley Wendel, Government Lawyers in the Trump Administration, __ HASTINGS L.J. _ _ (2017) (forthcoming).

${ }^{43}$ See Memorandum to Alberto R. Gonzales from Jay S. Bybee (Aug. 1, 2002), reprinted in The Torture Papers: The RoAd to ABu GhraiB 172 (Karen J. Greenberg \& Joshua Dratel. eds., 2005).

${ }^{44}$ OPR REPORT, supra note _ _, at 166 (reporting that Yoo had stated in interviews that, regarding the specific-intent analysis, he had "only looked at cases quickly," was working from a recollection of a law review or treatise, and got the impression from talking with criminal law specialists at the Justice Department that it was a "knowing it when I see it" standard). 
cite and discuss contrary authority, such as the Steel Seizure Case, which is the leading Supreme Court precedent on the President's authority vis-à-vis Congress in national security matters. ${ }^{45}$ The analysis of complex, subtle issues was sometimes oversimplified to the point of being misleading, ${ }^{46}$ and often failed to acknowledge ambiguities, limitations, or counterarguments. ${ }^{47}$ One of the most notorious mistakes made by the lawyers was to analogize a criminal statute prohibiting torture to a statute defining medical benefits, resulting in a definition of severe pain as that which accompanies organ failure. $^{48}$

\section{BAD LEgAl AdVICE: ITS CAUSES AND CURES - A SHORT History}

\section{A. Decline and Fall of the Professional Ideal}

Early Twentieth Century theories of social control allocated a significant role to professionals to ensure that the social order embodied shared values. ${ }^{49}$ Lawyers on this account were obligated not to seek the advantage of their clients, but instead bring to bear their expertise in "understanding complex facts" and "us[ing] those facts to envision a new and better community." ${ }^{\circ 0}$ In sociology, Talcott Parsons contended that "the lawyer stands as a kind of buffer between the illegitimate desires of his clients and the social interest."51 On this account, a lawyer should serve as a "wise counselor" who does not merely manipulate legal rules for the benefit of clients, but nudges powerful individuals and corporations in the direction of socially responsible behavior. $^{52}$ The traditional conception of professionalism is unapologetic in

${ }^{45}$ Id. at 204 (citing Youngstown Sheet \& Tube Co. v. Sawyer, 343 U.S. 579 (1952)).

${ }^{46}$ Id. at $168-73$ (noting that Bybee had read a Supreme Court case dealing with the element of willfulness as bearing on the proper understanding of specific intent); id. at 18486 (criticizing memo for oversimplifying ratification history of Convention Against Torture).

${ }^{47}$ Id. at 174-75 (observing that memo failed to mention that good faith defense developed in the context of tax and financial crimes, may not apply in the same manner to a mala in se crime like torture, and in any event may be limited by willful blindness); id. at 181 n.135 (criticizing authors for not acknowledging that "severe pain" was given inconsistent definitions in statutes); id. at 201-03 (noting that analysis of Commander-inChief power did not acknowledge the limitation as applied to such as basic norm as the prohibition on torture).

${ }^{48} \mathrm{Id}$. at 178.

49 Paul D. Carrington, Stewards of Democracy: LAW as a PubliC Profession (1999); SAMuel Haber, THE Quest FOR Authority AND HONOR IN THE AMERICAN PROFESSIONS 1750-1900 (1991).

50 See Harlan Fiske Stone, The Public Influence of the Bar, 48 HARV. L. REV. 1, 14 (1934).

${ }^{51}$ Talcott Parsons, A Sociologist Looks at the Legal Profession, in Essays in Sociological Theory 384 (rev. ed. 1954).

52 Anthony T. KRONMAn, The LOST LAWYeR (1993); Robert W. Gordon, Why Lawyers 
its assumption that lawyers have better access than clients to knowledge of the common good for society. Or, to use the term associated with the civic republican tradition, lawyers are in a better position than their clients, or for that matter official legal institutions like legislatures and courts, to exercise civic virtue - that is, an impartiality among private interests, with due concern for the public good or general welfare of society. ${ }^{53}$

There is at least some anecdotal evidence that large-firm lawyers once enjoyed sufficient independence to resist pressure from clients to assist with conduct that was contrary to the public interest. ${ }^{54}$ William Simon has argued that Louis D. Brandeis, in his private practice career before his appointment to the U.S. Supreme Court, exemplified features of the traditional conception of professional practice in his day. ${ }^{55}$ These include attempting to dissuade powerful institutional clients from "unjust or antisocial projects" and considering the interests of third parties with whom their clients were dealing. Brandeis was an example of a lawyer who saw his job as establishing "frameworks of fair and mutually beneficial cooperation," 56 not merely pressing for the private advantages of his clients. Brandeis's Supreme Court confirmation hearings generated considerable controversy. He was a Progressive who had made enemies of powerful railroad magnates in New England; he was no radical, but he did contend that big business should be more responsible to the public interest. ${ }^{57}$ Opponents of his confirmation attacked him as duplicitous, untrustworthy, unscrupulous, and known to engage in "sharp practice." ${ }^{58}$ While this opposition may have resulted more from anti-Semitism and political disagreement than any genuine concern

Can't Just Be Hired Guns, in Ethics in Practice: LAwYers’ Roles, Responsibilities, AND REgulation 46 (Deborah L. Rhode, ed., 2000); Russell G. Pearce, Rediscovering the Republican Origins of the Legal Ethics Codes, 6 GEO. J. LEGAL ETHICS 241 (1992); Robert W. Gordon, The Independence of Lawyers, 68 B.U. L. REV. 1 (1988); Robert A. Kagan \& Robert Eli Rosen, On the Social Significance of Large Law Firm Practice, 37 STAN. L. REV. 339, 410 (1985).

${ }^{53}$ Gordon, supra note __, at 14-15 (quoting Alexander Hamilton, Federalist No. 35).

${ }^{54}$ GLEndON, supra note _ , at 32-38. See also HABER, supra note _ , at 224 (noting the Gilded Age anxiety about the "lawyer as hired man" who does his client's bidding without regard to the demands of justice); id. at 238 (reporting ABA President Thomas Cooley’s opposition to "trusts" and concentration of business power and wealth).

${ }^{55}$ William H. SimON, THE PRACTICE OF JUSTICE 128-29 (1998).

${ }^{56}$ Id. at 131; see also David Luban, The Noblesse Oblige Tradition in the Practice of Law, 41 VAND. L. REV. 717, 722 (1988) (arguing that Brandeis was more of a social engineer than a radical reformer).

57 See, e.g., JEROLD S. AuERBACH, UnEQUAL JustiCE: LAWYERS AND SOCIAL CHANGE IN MODERn AMERICA 66-73 (1976); John P. Frank, The Legal Ethics of Louis D. Brandeis, 17 STAN. L. REV. 683 (1965).

${ }^{58}$ AUERBACH, supra note _, at 71. 
about Brandeis's ethics, ${ }^{59}$ the controversy does belie the claim that Brandeis embodied generally accepted ideals of professionalism. Even at the time the traditional model of professionalism may not have been the dominant ideal.

From the standpoint of the early Twenty-first Century, however, the traditional conception of professionalism appears to be mostly a museum piece. Nowadays the dominant model of legal advising holds that lawyers are permitted to seek any advantage for clients that can be obtained through lawful means. On what has been called the "libertarian-positivist" view, ${ }^{60}$ lawyers represent clients who are merely self-interested, pursuing their own ends, within constraints established by positive law. Anything not clearly prohibited is permitted, and it is the duty of the lawyer to maximize the client's freedom of action. Lawyers are fundamentally technicians, retained by clients for their expertise in working with complex legal doctrines - again, with the end of facilitating the autonomy of clients to act on their own interests. ${ }^{61}$ They have no expertise in ascertaining the common good of the community, nor of harmonizing the interests of clients with those of society as a whole. Lawyers do not serve the public interest, but the ends of their clients, and should do so with diligence, competence, and "warm zeal.",62

Some of the reasons for the decline of the professional ideal, such as the increase in bureaucratization and billable hour pressures, and heightened competition among law firms aided and abetted by the in-house counsel movement, ${ }^{63}$ are of considerable interest to legal sociologists and historians, but are peripheral to the normative analysis here. What is important for this discussion is the loss of faith in the existence or knowability of the common good, the public interest, or the general will. ${ }^{64}$

59 See Samuel J. Levine, Rediscovering Julius Henry Cohen and the Origins of the Business/Profession Dichotomy: A Study in the Discourse of Early Twentieth Century Legal Professionalism, 47 AM. J. LEG. HIST. 1 (2005).

${ }^{60}$ Simon, supra note _ _, at 26-29 (describing the position to criticize it).

${ }^{61}$ Stephen L. Pepper, The Lawyer's Amoral Ethical Role: A Defense, A Problem, and Some Possibilities, 1986 AM. B. Found. RES. J. 613.

62 See AmEricAn BAR Ass'n, CANONS OF Prof'L Ethics, Canon 15 (1908) ("a lawyer owes entire devotion to the interest of the client, warm zeal in the maintenance and defense of his rights and the exertion of his utmost learning and ability”).

${ }^{63}$ See, e.g., ROBERT L. NELSON, PARTNERS WITH POWER: SOCIAL TRANSFORMATION OF THE LARGE LAW FIRM (1988); Marc Galanter \& Thomas Palay, The Transformation of the Big Law Firm, in LAWYERS' IDEALS/LAWYERS’ PRACTICES: TRANSFORMATIONS IN THE American Legal Profession 31 (Robert L. Nelson, et al., eds. 1992); ThOMAS D. Morgan, The VAnishing AmErican LAWYer (2010); MARy ANn GLENDON, A NATiON UNDER LAWYERS 37 (1994); KRONMAN, supra note _, at 283-91.

${ }^{64}$ Roiphe, supra note _, at 665, 668, 672-75. 
Broadly speaking, this loss of faith has two causes, according to Rebecca Roiphe. 65 The first is the insistence on the individual as the unit of analysis and the reductionist conception of society as nothing more than the aggregation of individual preferences. Critics with Jacksonian sympathies throughout American history have always been hostile to the idea of a political elite who get to tell others what was in the public interest, but in the mid-Twentieth Century, public-choice theorists severely criticized any nonaggregative conception of the common good itself. ${ }^{66}$ Neo-classical economists understand society as nothing more than an arena of competition for atomistic individuals pursuing their own interests, constrained only by the deterrent effect of sanctions for unlawful conduct. Rather than analyze the interests of the state or some other collectivity, political scientists begin with the individual as the unit of analysis. The state, then, is "nothing more than the set of processes, the machine, which allows . . . collective action to take place." 67 Government policy is then understood as the outcome of a competition among interested individuals and groups who are seeking to maximize their own utility. There is no such thing as the public interest, only "individual decisions [as] combined through a specific rule of decisionmaking." 68

Taking this methodological assumption to its logical limit, one can insist that a theorist not make reference to the interests of some mysterious abstract entity like "society." If what some call "society" is nothing more than a bunch of individual people making choices, based on their self-interest, talk of the common good by professionals must be either empty or self-serving, because the common good is a chimera. To put the point more in legal-process terms, one might contend that the common good or the public interest is merely the label that is applied to the result of a political process for determining the substance of public policy. In an influential article, Geoffrey Miller criticized the view (still quite prevalent ${ }^{69}$ ) that lawyers working for government (2016).

${ }^{65}$ See Rebecca Roiphe, The Decline of Professionalism, 29 Geo. J. Legal Ethics 649

${ }^{66}$ See, e.g., RICHARD A. POSNER, ECONOMIC ANALYSIS OF LAW § 19.3, at 572 (5th ed. 1998) (summarizing public-choice position and citing foundational works); William N. Eskridge, Jr., Politics Without Romance: Implications of Public Choice Theory for Statutory Interpretation, 74 VA. L. REV. 275 (1988); Frank H. Easterbrook, Statutes' Domains, 50 U. CHI. L. REV. 533 (1983).

${ }^{67}$ James M. BuChanan \& GORdON TUlLOCK, The CALCulus OF CONSENT 13 (1962).

${ }^{68}$ Id. at 35; see also HABER, supra note _, at 215-19 (noting that in the late Nineteenth Century the source of legitimacy of law shifted from Blackstonian conceptions of natural law to the habits and customs of the people, as reflected in the choices made by self-interested individuals).

${ }^{69}$ See, e.g., Steven K. Berenson, Public Lawyers, Private Values: Can, Should, and Will Government Lawyers Serve the Public Interest?, 41 B.C. L. REV. 789 (2000). 
agencies ought to take the public interest into account when providing legal advice. ${ }^{70}$ A lawyer should not act on her own conception of the public interest, because the Constitution establishes a procedure for approximating the content of this ideal, through elections, political appointment of agency heads, and so on. For Miller, the problem is not epistemic; that is, it is not that lawyers do not have the capacity to discern and advice clients on the content of the public interest. Rather, the problem is that there are multiple, plausible conceptions of the public interest that bear on most interesting policy issues. His example involves a lawyer working for the Department of Education who is called upon to advise on a new program to provide federal funding for asbestos abatement in religiously affiliated schools. Which is more consistent with the public interest - strict church/state separation or the limited entanglement of government funding and religious schooling? An attorney, like any other thoughtful person, might believe herself to be correct in her view about what the public interest requires. Miller's point, however, is that insofar as she is acting as an attorney, a thoughtful person who has beliefs about the public interest must act only on democratically legitimate conceptions of the public interest. ${ }^{71}$

Contrary to the claim that lawyers are neither capitalists nor labor, but some kind of intermediate, independent institution, ${ }^{72}$ the emerging ideology of the market regarded lawyers as producers of something called "legal services." Lawyers are certainly service providers, but the shift in emphasis from the common good to the autonomy and utility-maximizing of individual clients undercuts the claim of lawyers to distinctive professional expertise. Historically speaking it seems to be the case that lawyers' connection to the common good or the public interest became sufficiently attenuated that their claim to be a type of quasi-public actors began to sound anachronistic and self-serving. As early as 1932, Supreme Court Justice Harlan F. Stone was calling corporate lawyers the "obsequious servant[s] of business" who no longer had the capacity or the inclination for "bringing the law into harmony with changed conditions," because they were "tainted by the morals and manners of the market place in all its most anti-social manifestations." 73 It was then but a small step to affirmatively valorizing the "morals and manners of the market place” and contending that legal professionalism was reducible

${ }^{70}$ Geoffrey P. Miller, Government Lawyers’ Ethics in a System of Checks and Balances, 54 U. CHI. L. REV. 1293 (1987). See also Jonathan R. Macey \& Geoffrey P. Miller, Reflections on Professional Responsibility in a Regulatory State, 63 GEO. WASH. L. REV. 1105 (1995); John O. McGinnis, Models of the Opinion Function of the Attorney General: A Normative, Descriptive, and Historical Prolegomenon, 15 CARDOZO L. REV. 375 (1994).

${ }^{71}$ Miller, supra note _, at 1297.

${ }^{72}$ HABER, supra note _ , at 237.

${ }^{73}$ Stone, supra note _, at 7. 
to economic efficiency. Clients purchase services from lawyers for a price, and expect a return on their investment. In the modern era, some sophisticated corporate clients - most famously, General Electric Corporation - have explicitly reconceptualized their in-house legal departments as profit centers, tasked with managing legal risks and controlling legal costs. ${ }^{74}$

The second cause of the loss of faith is the renewed appreciation for the fact of moral pluralism, following the work of Isaiah Berlin, the later Rawls, John Finnis, Joseph Raz, and other political theorists. ${ }^{75}$ Objectively speaking, it is the case that human goods and virtues are not all aspects of a single ideal of a well-lived life. As Isaiah Berlin argued, "the belief that some single formula can in principle be found whereby all the diverse ends of men can be harmoniously realized is demonstrably false."76 People care about different things that are, themselves, all genuine goods. The problem of governing a community is not merely ranking or prioritizing competing values, but dealing with conceptions of the good life that cannot be reduced to others, or to some overarching ideal under which all others can be compared.

The core claim of natural law theory is that law is "[a]n ordinance of reason for the common good, made by him who has care of the community, and promulgated," 77 but if pressed, even a natural law theorist might agree that the idea of the common good is incoherent as a source of practical guidance. Aquinas, for example, observes that rulers who are entrusted with the care of the community must do their best to understand how the eternal law ought to be specified as concrete rules for the governance of society, but as fallible humans they are prone to make mistakes and perceive divine law only imperfectly. ${ }^{78}$ Finnis has a more modern view which begins with the

\footnotetext{
${ }^{74}$ See, e.g., BEN W. HEINEMAN, JR., THE InSIDE COUNSEL REVOLUTION: RESOLVING THE Partner-GuARdian TEnsion (2016); Ben W. Heineman, Jr., The Rise of the General Counsel, HARV. BuS. REV. (Sept. 27, 2012).

75 Jeremy WaldRon, LAW AND DisagreEMENT (1999); JoHn RAWLS, Political LiBERAlisM (1993); IsAiAH BERLIN, THE CROOKED TIMBER OF HuMANITY (Henry Hardy, ed. 1990); JOSEPH RAZ, THE MORALITY OF FREEDOM (1986); JOHN FINNIS, NATURAL LAW AND NATURAL RIGHTS (1980).

${ }^{76}$ Isaiah Berlin, Two Concepts of Liberty, in THE PROPER STUDY OF MANKIND 191, 239 (Henry Hardy \& Roger Hausheer, eds., 1998).

77 Thomas Aquinas, Summa Theologica, sec. 90, in AQUINAS ON LAW, MORALITY, AND Politics (William P. Baumgarth \& Richard J. Regan, eds., 2d ed., 2002); see also CiCERO, ON DuTIES (Walter Miller, trans., 1913). For modern versions of the natural law thesis that law is, conceptually speaking, something having to do with the common good of the political community, see MARK C. MurPhy, NATURAL LAW IN JURISPRUDENCE AND POLITICS 61-63 (2006); FINNIS, supra note _, at 154-56.

${ }^{78}$ Aquinas, supra note _ _, at Q91, 3 (“[H]uman reason cannot have a full participation of the dictate of the Divine Reason, but according to its own mode, and imperfectly.”).
} 
recognition of the objective fact of the pluralism and incommensurability of basic goods. ${ }^{79}$ A political community faces coordination problems when its citizens try to use reason alone to determine the weight and priority of these basic goods. Realizing the common good for the community requires resolution of these coordination problems. "Authority (and thus the responsibility of governing) in a community is to be exercised by those who can in fact effectively settle coordination problems for that community." 80 One acts for the sake of the common good by acting on the requirements of law, which function as an authority to coordinate what would otherwise be conflicting views about what the common good requires. ${ }^{81}$

Finnis's argument from coordination and authority suggests a thinner conception of the common good as nothing more than procedural justice. ${ }^{82}$ If the common good is something that is arrived at, not discovered, and if it is something about which reasonable disagreement is not only possible but expected, then it follows that the role of legal advisors should be understood in terms of facilitating the engagement of citizens with the process of political decisionmaking. ${ }^{83}$ The underlying political-moral ideal is the autonomy of citizens to make uncoerced choices about the projects they will pursue. ${ }^{84}$ As it happened, a conception of ethical lawyering that emphasized client autonomy and relieved lawyers of the burdens of aligning the interests of clients with the common good became the dominant model of legal advising by the middle of the Twentieth Century. ${ }^{85}$

\section{B. The Standard Conception, Old-School and Modern}

Methodological individualism and the recognition of ethical pluralism grounded a mutually reinforcing assault upon the vision of lawyers as social engineers or custodians of the common good. What replaced it came to be known as the standard conception of legal ethics. Familiarly, it maintains that a lawyer's job is to be a zealous advocate for the interests of her client, within the bounds of the law. ${ }^{86}$ This model of legal advising instantiates an ethical

\footnotetext{
${ }^{79}$ FINNIS, supra note _, at 115.

${ }^{80} \mathrm{Id}$. at 246 (emphasis in original).

${ }^{81} \mathrm{Id}$. at 316-20.

${ }^{82}$ STUART HAMPSHIRE, MORALITY AND CONFLICT (1983).

${ }^{83}$ DANiEl Markovits, A Modern Legal Ethics (2008).

${ }^{84} \mathrm{RAZ}$, supra note _, at 369-72.

${ }^{85}$ See Roiphe, supra note _, at 672.

${ }^{86}$ See Murray Schwartz, The Professionalism and Accountability of Lawyers, 66 CAL.
} L. REV. 669 (1978) (setting out elements of the standard conception). The label "standard conception” originated with an influential article by Gerald Postema. See Gerald J. Postema, Moral Responsibility in Professional Ethics, 55 N.Y.U. L. REV. 63, 73 (1980). 
division of labor between lawyer and client. ${ }^{87}$ The client determines the objectives of the representation, after consultation with the lawyer, and the lawyer has discretion to choose the means by which the client's ends will be accomplished. Any responsibility for the substantive ends of the representation attaches solely to the client. As long as the lawyer stays within legal limits, any accountability for the means chosen by the lawyer is externalized to the legal system itself. In moral terms, the standard conception respects the ethical value of autonomy, and ensures that the client's liberty will not be restricted by well-meaning lawyers who exceed the bounds of their authority to impose idiosyncratic moral limits on their clients' actions. ${ }^{88}$ In other words, the standard conception enforces the conceptual separability of law and morality. ${ }^{89}$

The standard conception has been criticized as rendering the lawyer "at best systematically amoral and at worst more than occasionally immoral,"90 as judged by the standards one would ordinarily apply to an individual's conduct. Much of the scholarly analysis of the standard conception focuses on its impact on the moral agency of lawyers. ${ }^{91}$ A different question, which has received less attention, is whether the standard conception errs by assuming a discredited or disreputable theory about the nature of law. A political-moral theory of the ideal of the rule of law shows a different limitation of the standard conception and suggests a better way to reconstruct an account of legal advising.

\section{The Holmesian Bad Man Stance}

The correlative attitude to the standard conception, from the client's point of view, was well described by former White House Counsel Robert F. Bauer. Asked to characterize President Trump as a client, Bauer stated that, based on the public record, Trump

\footnotetext{
${ }^{87}$ See, e.g., Norman W. Spaulding, The Privilege of Probity: Forgotten Foundations of the Attorney-Client Privilege, 26 GEO. J. LEGAL ETHICS 301 (2013) (arguing that the best way to understand the policies underlying the attorney-client privilege is functionally, enabling the attorney and client to deliberate confidentially about the legality of a proposed course of conduct, with the final decision whether to comply with the law being the client's).

${ }^{88}$ Stephen L. Pepper, The Lawyer's Amoral Ethical Role: A Defense, A Problem, and Some Possibilities, 1986 AM. B. Found. RES. J. 613; Charles Fried, The Lawyer as Friend: The Moral Foundations of the Lawyer-Client Relation, 85 YALE L.J. 1060 (1976).

${ }^{89}$ See W. Bradley Wendel, Legal Ethics and the Separation of Law and Morals, 91 CORNELL L. REV. 67 (2005).

${ }^{90}$ Richard Wasserstrom, Lawyers as Professionals: Some Moral Issues, 5 HuM. RTS. 1 (1975).

${ }^{91}$ See, e.g., ARTHUR ISAK APPLBAUM, ETHICS FOR ADVERSARIES (1999); DAVID LUBAN, LAWYERS AND JUSTICE (1988); Postema, supra note
} 
has a very instrumental view of the law that he carries over from the private sector, and therefore a very instrumental view of the role of lawyers. The law is something that pops up in the course of his affairs that should be managed, and managed to a particular outcome, to a particular result that he wants, and the best lawyers are the ones that get that for him. ${ }^{92}$

One difficult with the standard conception is that a client may view the law instrumentally, as nothing more than an obstacle standing in the way of his freely-chosen ends. The idea is that compliance with the law does not have any intrinsic to-be-doneness about it, but is only valuable instrumentally, that is, as a means to something else. If a course of action presents a risk of legal sanctions, the client needs to know that in order to avoid an expensive and time-consuming entanglement with enforcement authorities. But apart from prudential considerations, there is nothing about the law that creates reasons the client must take into account when deciding what do to.

This is, of course, the well-known Holmesian bad man perspective on the law, also known as the law-as-price theory - a crude form of legal realism. ${ }^{93}$

${ }^{92}$ Lawfare Podcast: Bob Bauer on Trump and the White House Counsel (May 27, 2017), available at https://www.lawfareblog.com/lawfare-podcast-bob-bauer-trump-and-whitehouse-counsel.

${ }^{93}$ See Oliver Wendell Holmes, Jr., The Path of the Law, 10 HARV. L. REV. 457, 459-62 (1897). See also Frank H. Easterbrook \& Daniel R. Fischel, Antitrust Suits by Targets of Tender Offers, 80 МicH. L. REV. 1155, 1168 (1982) (arguing that rational corporate managers ought to treat legal norms as a form of price or tax, not an outright prohibition); Randal N.M. Graham, Morality v. Markets: An Economic Account of Legal Ethics, 8 LEGAL ETHICS 87 (2005) (arguing broadly, across a range of laws, that a fine or penalty can be understood as a price or tax); see also Cynthia A. Williams, Corporate Compliance with the Law in the Era of Efficiency, 76 N.C. L. REV. 1265 (1998) (criticizing this position); Donald C. Langevoort, Someplace Between Philosophy and Economics: Legitimacy and Good Corporate Lawyering, 75 FORDHAM L. REV. 1615 (2006) (reviewing the debate and arguing for a middle ground position in which the normativity of law is related to considerations of legitimacy) see also Kenneth J. Arrow, Social Responsibility and Economic Efficiency, 21 PUB. POL'Y 303, 314 (1973) ("Every contract depends for its observance on a mass of unspecified conditions which suggest that performance will be carried out in good faith without insistence on sticking literally to its wording."). Law-and-economic theorists tend to assert the proposition that legal prohibitions are nothing more than a price as an ipse dixit with no supporting argument. See David Luban, The Bad Man and the Good Lawyer: A Centennial Essay on Holmes's The Path of the Law, 72 N.Y.U. L. ReV. 1547, 1565-66 (1997). Holmes argued that a sufficient theoretical account of law could proceed from the point of view of a hypothetical "bad man" who was concerned only to avoid legal sanctions. The law-as-price theory expands the Holmesian bad man predictive orientation toward law 
The role of the lawyer on this view is simply to provide technical expertise that enables the client to accomplish its ends, along with a fairly thin constraint on providing knowing assistance in conduct the lawyer knows is criminal or fraudulent. That price would presumably also be reduced by the probability of detection and punishment, so that if the activity could successfully be hidden, or if lawyers could throw enough sand in the machinery of the criminal, civil litigation, or administrative process to forestall monetary penalties, then the corporation could engage in even more profitable activity. ${ }^{94}$ The upshot is that client, and hence the lawyer as well, will tend to regard the law "in a wholly alienated and instrumental fashion" and not as a set of norms established in the name of the political community for the end of its governance. ${ }^{95}$

The limits of the Holmesian bad man perspective as a theoretical account of law is illustrated by its inability to differentiate a legal permission to engage in activity from an instance of non-detection or non-punishment of client wrongdoing made possible by bribery, destruction of evidence, or a scorched-earth defense campaign waged by lawyers. ${ }^{96}$ This is one conceptual objection to the Holmesian bad man theory. I am interested here in a different conceptual critique, which focuses on the inadequacy of a purely instrumental account of the reasons given by law to explain the significance of law as a social and political institution. This inadequacy relates further to the function of law in a pluralist society, which is to furnish the means by which one member of the community can offer a political justification to another, in the name of the community as a whole, for an action that affects the other's

into a distinctive theory of entitlement. According to law-as-price, one has a right to violate the law which can be obtained simply by "purchasing" the associated penalty, or willingly incurring a risk of the penalty. See Williams, supra, at 1268.

${ }^{94}$ To be fair, proponents of the law-as-price theory restrict it to malum prohibitum offenses, and would agree that prohibitions on rape, murder, and fraud should not be reduced to prices or taxes that seek to produce the optimal level of some activity. See Easterbrook \& Fischel, supra note _ , at 1168 n.36. Their point is that there are independent moral reasons not to engage in rape, murder, or fraud, so the law makes no difference to the balance of reasons agents have with respect to those activities.

${ }^{95}$ Robert W. Gordon, Law as a Vocation: Holmes and the Lawyer's Path, in THE PATH OF THE LAW AND ITS INFLUENCE 7, 13 (Steven J. Burton ed. 2000).

${ }_{96}$ As H.L.A. Hart argued with devastating effect against a similar theoretical move by John Austin, a theory is deficient to the extent it cannot account for the attitude that many of its subjects take, much of the time. Many citizens are more like the "puzzled man" than Holmes's bad man, and are sincerely interested in learning what the law requires of them or permits them to do. See H.L.A. HART, THE CONCEPT OF LAW 56, 82 (2d ed. 1994); see also DAVID LYONS, ETHICS AND THE RULE OF LAW 71 (1984). The reasons created by legal rights are related to the nature of law as normative and social, and dependent upon the law's capacity to create reasons (its normativity) and its relationship to citizens' understanding of their obligations to others in the political community (its social character). 
interests. The Holmesian bad man perspective renders one capable only of making statements like, "If I do this to you, bad things won't happen to me.” What the addressee is looking for, however, is a reasoned justification for why the action is permissible, in terms the addressee can accept. The absence of sanctions for doing something does not furnish this type of reason.

The usual way of making the critique of the Holmesian bad man perspective is to focus on the authority of law, as Joseph Raz has done. ${ }^{97}$ The law by its nature claims to be normative. The whole point of law is to affect its subjects' set of reasons for action; that is, the law must be something that is capable of possessing authority. For anything to function as an authority, it must both reflect and replace the reasons moral agents already have, prior to their engagement with the authority. Authorities serve agents, by helping them to better at what they already have reason to do. ${ }^{98}$ However, they do not merely furnish an additional reason, but they are based upon, and preempt, the reasons that otherwise apply. ${ }^{99}$ As applied to theoretical authorities, this pattern of justification is fairly intuitive. If I want to know if there will be thunderstorms in the afternoon, I will do better if I rely on the forecast prepared by the National Weather Service than if I try to figure it out on my own based on what I am able to observe. Practical authorities, like the law, can be a real puzzle, however. Reliance on a practical authority seems to involve abdicating one's agency, surrendering one's judgment, or what Sartre would call acting in bad faith.

The answer to this objection is also the starting point for a model of legal advising that takes as central the situation of rational agents attempting to forge a common society among persons who understand each other as free and equal. Citizens in a democracy are said to be self-governing, but of course this is as much a metaphor as a literal truth. Individuals and entities in a democratic society are subject to legal restraints, and empowered by law with rights effective against other citizens and against the state, and also with the means of private ordering, such as corporations and trusts. These legal rights and duties are arrived at through decisionmaking procedures that are broadly majoritarian, but subject to constitutional limitations intended to, among other things, protect basic political liberties such as freedom of conscience and expression, and rights to equality in political participation. In Rousseau's influential account, we are all free by nature, but vulnerable to exploitation

${ }_{97}$ Joseph Raz, Authority, Law and Morality, in Ethics IN THE PuBliC Domain 210 (1994).

98 Joseph Raz, the Morality of Freedom 56 (1986) (articulating a "service conception" of authorities as serving the governed).

${ }^{99} \mathrm{Id}$. at $41-42$ 
by those stronger than us. In forming a republic, however, people remain free because while they are subjects of the sovereign authority of the state, they are also citizens, meaning that they share in the power of directing the body politic. ${ }^{100}$ Citizens do this most obviously by voting, but also by participating in other ways in the process of determining the general will or the common good. ${ }^{101}$ In contrast with pure majoritarian accounts of democracy, or publicchoice theories that emphasize competition by organized interest groups for scarce public goods, theorists influenced by Rousseau take political decisionmaking to be aimed at ascertaining the content of the common good. ${ }^{102}$ When a matter is put to a vote, there will be winners and losers in a numerical sense, but the losers should still accept the result as legitimate. Why? Because, on one account, democratic decision-making procedures are more reliable than any other at tracking the common good of a society. ${ }^{103}$ Alternatively, if one is skeptical about the determinacy of the common good, positive law establishes "a single, determinate community position on the matter."104

To understand the importance of the proviso, "from the point of view of the political community," consider Wollheim's paradox of democracy: Suppose you believe deer hunting ought not to be allowed. You are also committed to government by democracy. The majority in your jurisdiction votes to allow deer hunting. Now, you allegedly believe two incompatible

100 J.J. ROUSSEAU, THE SOCIAL CONTRACT, Book I, vi.

101 There is an extensive literature on the concept of the general will in Rousseau. Very generally speaking, it can be identified with either (1) what citizens have decided together in a common assembly - a procedural or majoritarian conception; or (2) an ideal representing the common interests of society, independent of what an assembly of citizens happens to vote for, but which the assembly should strive to discern. See, e.g., ANDREW LEVINE, THE GENERAL WILL (1993); Gopal Sreenivasan, What is the General Will?, 109 PHIL. REV. 545 (2000); Joshua Cohen, Reflections on Rousseau: Autonomy and Democracy, 15 PHIL. \& PUB. AfF. 275 (1986). It seems clear from The Social Contract, Book II, iii ("[t]here is often considerable difference between the will of all and the general will") that the general will is not reducible to an aggregation of individual preferences, i.e. "the sum of individual wills." See also id., Book II, iv ("What makes the will general is not the number of citizens concerned but the common interest by which they are united.”). However, my interest here is not getting the interpretation of Rousseau right, but exploring how political theory and professional ethics can be related. I believe it is correct to adopt the second conception of the general will, synonymous with the common good of the community, but the argument in this section does not depend on this reading.

102 Jeremy Waldron, Rights and Majorities: Rousseau Revisited, in LIBERAL RIGHTS 392, 399 (1993).

103 A. John Simmons, Political Philosophy 110 (2008). This is an epistemic account of democratic legitimacy, which holds that the majority's decisionmaking procedure is legitimate because it is better than any alternative at tracking the general will.

104 Jeremy Waldron, Kant's Legal Positivism, 109 HARV. L. REV. 1535, 1540 (1996). 
things - that deer hunting ought to be prohibited, and that it ought to be allowed. ${ }^{105}$ There is no paradox, however, if you believe that the majority has a right to implement a decision for all citizens of the political community, arrived at using fair democratic procedures. ${ }^{106}$ That is, you believe in the legitimacy of democratic decision-making. If you do, however, you are committed to the view that legitimate laws embody a social judgment about what citizens ought to do, or not to do. In that case, the social judgment concerning what may or may not be done (for example, that deer hunting is permitted) becomes the reason for individuals to do, or not do, something. Someone who says, "I am legally permitted to engage in deer hunting," is offering a particular type of reason in justification for his actions. The reason implicitly refers to the capacity of the legal system to consider opposing points of view and competing arguments, and to settle on a position that is to be adopted in the name of society as a whole. ${ }^{107} \mathrm{~A}$ strong conception of the function of this type of reasons would see them as exclusionary, ${ }^{108}$ as replacing reasons one would otherwise have to engage in deer hunting, or not. One need not go as far as regarding legal reasons as exclusionary. It is, however, an aspect of the nature of law - what it means for something to be law and not something else, like a price or a tax - that the law claims to confer rights and duties upon its subjects. ${ }^{109}$ It follows that, when a legal interpreter is seeking to discover the position of the law with respect to some matter, she by definition is determining something that purports to be collective, social, and an in a modern, complex legal system, institutional.

A caveat is in order at this point. I have adopted language from Hart and Sacks in contending that legal rights and duties are established in the name of society as a whole. ${ }^{110}$ Admittedly, this is a schematic and somewhat imprecise way of making the point, and talking in terms of what "we" have enacted into law has the potential to conceal illegitimate hierarchies and

105 See Richard Wollheim, A Paradox in the Theory of Democracy, in PHILOSOPHY, Politics AND Society: SeCOND SeRIES 71 (Peter Laslett and W. G. Runciman, eds., 1962). The deer hunting version is from Amy Gutmann, Democracy, in A COMPANION TO CONTEMPORARY Political Philosophy 528-29 (Robert E. Goodin, et al., eds. 2d ed. 2012).

${ }^{106}$ See, e.g., J. Roland Pennock, Democracy is Not Paradoxical, 2 POL. THEORY 88 (1974).

${ }^{107}$ An attractive way of phrasing this point, which I believe I originally picked up from Rawls's "Reply to Habermas," is that political reasons must be stated in the first-person plural. See John Rawls, Reply to Habermas, in Political LiBERAlism 372, 378 (1993).

108 JOSEPH RAZ, THE AUTHORITY OF LAW 17 (1979). I have used Raz's notion of exclusionary reasons in arguing for the preemptive effect of law on the moral deliberation of lawyers. See WENDEL, supra note _, at 111-12.

109 JOSEPH RAZ, BETWEEN AUTHORITY AND INTERPRETATION 2 (2009).

${ }^{110}$ HART \& SACKS, supra note _, at 162. 
social injustices. ${ }^{111}$ In no way do I wish to deny that a law may be unjust, for reasons including its infliction by a majority upon a minority which had no voice in its enactment (King's "difference made legal"), ${ }^{112}$ or the disproportionate influence of big-money donors on electoral politics. Injustice is a pervasive feature of our legal system, but that does not change the underlying conceptual thesis that the law claims to have the normative authority to alter the balance of reasons for those subject to it, and to replace what would otherwise be the balance of reasons with a new reason established by those who exercise lawful authority. ${ }^{113}$

\section{The Internal Point of View and Its Limits}

A political theory of legal advising can accordingly be grounded in the same sorts of values that legitimate the exercise of political authority. Individuals and entities in a democratic society are subject to legal restraints, and empowered by law with rights effective against other citizens and against the state, and also with the means of private ordering, such as corporations and trusts. These legal rights and duties are arrived at through decisionmaking procedures that are broadly majoritarian, but subject to constitutional limitations intended to, among other things, protect basic political liberties such as freedom of conscience and expression, and rights to equality in political participation. Lawyers actually do perform a quasi-public role in a democratic polity, but not in the way imagined by Nineteenth Century theorists of professionalism. Rather than seeking to discover the substantive content of the common good, lawyers advise clients and structure social ordering around the rights and duties allocated to citizens by positive law. ${ }^{114}$

To use an idea made prominent by H.L.A. Hart, a lawyer advising her client should regard the law from the internal point of view, as creating genuine obligations, not merely enabling a prediction that a certain course of

\footnotetext{
${ }^{111}$ Waldron, supra note _, at 31 ("The we is bound up with whatever system of human power is in place in a given community.").

112 See Martin Luther King, Jr., Letter from Birmingham City Jail, in CIVIL DisobediEnCE IN Focus 68, 74 (Hugo Adam Bedau, ed., 1991).

113 Raz, ALM, supra note _, at 215-18.

114 See W. BRADLEY WENDEL, LAWYERS AND FIDELITY TO LAW (2010); TiM DARE, THE COUnSEL OF ROGUES? A DEFENCE OF THE STANDARD CONCEPTION OF THE LAWYER'S ROLE (2009); Alice Woolley, The Lawyer as Advisor and the Practice of the Rule of Law, 47 U.B.C. L. REV. 743 (2014); Norman W. Spaulding, Professional Independence in the Office of the Attorney General, 60 STAN. L. REV. 1931 (2007); see also Katherine R. Kruse, The Jurisprudential Turn in Legal Ethics, 53 ARIZ. L. REV. 493 (2011) (providing a sympathetic overview of this literature).
} 
conduct might result in the imposition of sanctions. ${ }^{115}$ Law accepted from the internal point of view establishes reasons for action, "guides for the conduct of life," and the basis of third-party attitudes such as "claims, demands, admissions, criticism, or punishment." 116 For Hart (who was concerned with the concept of law, not a theory of legal advising), however, there is no moral reason to adopt the internal point of view. Those who accept an obligationimposing legal rule - that is, those who accept the rule from the internal point of view - do not do so because they regard it as morally binding. ${ }^{117}$ Hart was concerned to remain clearly on one side of the great methodological divide between positivist and natural law theories, and insisted that "there are no necessary conceptual connections between the content of law and morality." 118 The subjects of the law may obey "for any motive whatsoever," 119 including the desire merely to avoid sanctions. Like the rules of a game, law accepted from the internal point of view states a rule that one ought to follow if one is playing the game; it does not, however, prescribe an "ought" to play the game in the first place. ${ }^{120}$

Hart's account does explain law's normativity in the same way that other sorts of obligations may arise. One is bound by chess-related obligations not to move a rook diagonally when playing chess. ${ }^{121}$ The normative force of

115 H.L.A. Hart, The Concept of Law 89-91 (2d ed. 1994). There is a great deal of commentary on this elusive idea. See, e.g., GERALD J. POSTEMA, LEGAL PhILOSOPHY IN THE TWENTIETH CENTURY: THE COMMON LAW WORLD 294-96 (2011); Scott Shapiro, What is the Internal Point of View?, 75 FORDHAM L. REV. 1157 (2007); Benjamin Zipursky, Legal Obligations and the Internal Aspect of Rules, 75 FORDHAM L. REV. 1229 (2007).

116 HART, supra note _, at 90.

117 See Stephen R. Perry, Hart's Methodological Positivism, 4 LEGAL THEORY 427, 447 (1998).

118 HART, supra note _, at 268.

${ }^{119}$ Id. at 116.

120 See Andrei Marmor, How Law is Like Chess, in LAW IN THE AGE OF PLURALISM 157 (2007).

${ }^{121}$ See FreDERICK SCHAUER, THE FORCE OF LAW 33-34 (2015). To understand the idea of a "chessal” obligation, imagine the conversation:

A: Hey, wait a second - you moved your rook diagonally. You can’t do that.

B: But I just did.

A: Yes, I can see that, but you can't do it - it's not permitted by the rules of the game.

$\mathrm{B}$ : Are you going to stop me?

The exchange is weird and literally incoherent. (I've heard a similar example attributed to Stephen Darwall: "Shut up, he argued," is nonsensical in the same way. I have been unable to find a citation.) In the chess example, the rules of the game constitute and make possible an activity having distinctive features and distinctive modes of explaining and justifying conduct. For example, an explanation might be: "Why did you do that?" "Because it pins the opponent's bishop - therefore it's a strong move.” The explanation necessarily presupposes 
such an obligation is presupposed by the voluntary act of sitting down to play chess. The judgment that one acts wrongly by moving a rook diagonally is therefore a "perspectival" judgment. ${ }^{122}$ From the internal perspective of some practice, accepting that practice as creating obligations for participants, an action can be judged as permissible or impermissible. Along these lines, one might therefore say that something is permitted or prohibited from the legal point of view, accepting the obligations from the internal point of view but remaining agnostic as to whether there are other types of obligations to do what the law prescribes. The trick here is that, for a legal positivist like Hart, it is essential that the law create content-independent reasons for those subject to it. ${ }^{123}$ The law as such must obligate, without considering whether the law requires something that is just or unjust.

But this does leave the idea of a legal obligation, understood in the same way as a social or "chessal" obligation, rather mysterious. ${ }^{124}$ Hart has pulled off the trick of explaining the way in which law is normative, without relying on what the subjects of law have moral reasons to do. Lon Fuller pointed this out in his contribution to the Hart-Fuller debate, ${ }^{125}$ and many of Hart's modern critics, like Stephen Perry and Jules Coleman, who are otherwise in the legal positivist camp, simply cannot see how accepting a scheme of rules (for chess, law, or whatever) from the internal point of view can give anyone an all-things-considered reason to do anything. ${ }^{126}$ Some of the best work by a new generation of legal philosophers accordingly seeks to go back to foundations, and explain the authority of law directly in terms of what we morally have reason to do.

In a recent paper, Scott Hershovitz argues against the idea that there is a distinctive domain of legal obligations. ${ }^{127}$ "[S]ome philosophers think that our legal practices generate a domain of legal reasons that is distinct from morality, prudence, and other sorts of reasons," ${ }^{128}$ he writes, and goes on to contend that legal obligation is part of a unified normative field which

the constitutive rules of the game. One cannot both claim to be within the game and refuse to accept the authority of the rules of the game. That is what it means to say one has an obligation-qua-chess not to make certain moves.

122 See SCOTT SHAPIRO, LEGALITY 185 (2011).

123 H.L.A. HART, ESSAYS ON BENTHAM 254-55 (1982).

124 Perry, supra note _, at 447.

${ }^{125}$ Lon L. Fuller, Positivism and Fidelity to Law: A Reply to Professor Hart, 71 HaRV. L. REV. 630 (1958).

126 Perry, supra note _, at 454; Jules L. Coleman, Reason and Authority, in THE AUTONOMY OF LAW: ESSAYS ON LEGAL PositiviSM 287 (Robert George ed. 1995).

${ }^{127}$ Scott Hershovitz, The End of Jurisprudence, 124 YALE L.J. 1160 (2015).

${ }^{128}$ Id. at 1165 n.5. 
includes morality. Mark Greenberg ${ }^{129}$ and John Gardner have also recently defended the position that there is a necessary connection between legal obligations and morality - that, as Gardner puts it, "legal reasoning is moral reasoning with one or more legal premises." 130 This contrasts with a view (which I've sometimes flirted with), ${ }^{131}$ which may be called "legal perpsectivalism." 132 On the perspectivalist view, the law purports to create genuine obligations, which may be moral - the law is agnostic on this point - to $\varphi$. Legal perspectivalism still has to explain how it can be that social facts, which for legal positivists are all that is relevant in determining the content of the law, can create obligations, whether moral or not. ${ }^{133}$ Hershovitz suggests the academic discipline of jurisprudence has been trapped in a Wittgensteinian fly-bottle, buzzing around trying to figure out how social practices and institutions can underwrite normative conclusions such as "I have a right to $\varphi$." His solution is to see law as continuous with other normative practices, like promising and making rules, and shift the burden of persuasion to anyone who would represent law as involving something distinctive, something different in kind from workaday practices the authority of which no one questions. ${ }^{134}$

Along very similar lines, Mark Greenberg argues that a lawyer working out what the law requires or permits a client to do must necessarily try to work out the balance of all morally relevant factors bearing on the client's situation. ${ }^{135}$ On this "moral impact theory" of law, determining the content of law is a matter of all-things-considered moral reasoning, including the morally relevant ways in which legal institutions alter the rights, duties, powers, privileges, etc., possessed by citizens. ${ }^{136}$ We can talk about what the law requires, but that is really just a roundabout way of saying what our moral

${ }^{129}$ See Mark Greenberg, The Moral Impact Theory of Law, 123 YALE L.J. 1288 (2014); Mark Greenberg, The Standard Picture and Its Discontents, in 1 OXFORD STUDIES IN PHILOSOPHY OF LAW 39 (Leslie Green \& Brian Leiter eds., 2011).

${ }^{130}$ JOHN GARDNER, LAW AS A LEAP OF FAITH ix (2012).

${ }^{131}$ See W. BRAdLEY WENDEL, ETHICS AND LAW: AN INTRODUCTION 70-74 (2014).

132 Christopher Essert, Legal Obligations and Reasons, 19 LEgAL THEORY 63 (2013); see also Greenberg, supra note _, at 1304 (citing Shapiro and Raz as legal positivists who have maintained that "to say there is a legal obligation is to say that, from the perspective of the legal system, there is a moral obligation").

${ }^{133}$ Shapiro calls this the DINO problem, for "descriptive inputs, normative outputs," and refers to this pattern of objections to legal positivism as Hume's challenge. See SHAPIRO, supra note _, at 47-48; see also Hershovitz, supra note _, at 1168 (noting that Hart's account of law seems to run afoul of Hume's warning against trying to derive an ought from an is).

\footnotetext{
${ }^{134}$ Hershovitz, supra note _, at 1193.

${ }^{135}$ Greenberg, supra note _, at 1329-30.

${ }^{136}$ Id. at $1302,1306,1310-11$.
} 
obligations are, in light of the impact of legal institutions. ${ }^{137}$ In many of these cases, the existence of a background moral obligation is relatively uncontroversial. For example, legal institutions may make determinate the obligations of morality that would otherwise be uncertain, make judicial findings of fact and resolve disputes, solve coordination problems, and prevent free-riding on beneficial cooperative schemes. ${ }^{138}$ Beyond determining or clarifying pre-existing obligations, legal institutions can, in appropriate circumstances, change what we have a moral obligation to do. ${ }^{139}$ These are the harder cases to explain on the moral-impact theory. Greenberg says that democratic considerations may alter citizens' moral profile; there is moral force to the existence of a procedure in which everyone has at least some opportunity to participate in. ${ }^{140}$ But he does not want to say that there is a general moral obligation to respect the laws enacted by a democratically elected legislature. ${ }^{141}$ Democratic considerations count in favor of a moral obligation to do what the legislature directs, but they are not conclusive of the existence of a moral obligation.

I wish to contend for something stronger than Greenberg's moral impact account - something closer to Raz's view that the law creates exclusionary reasons. ${ }^{142}$ In my view, a distinctive domain of legal obligation is necessary to provide a framework for cooperation in a society in which people are hopelessly divided over the content of moral obligations that exist apart from law. Go back to the example of the conduct revealed in the Panama Papers. Suppose there is at least one representation in which the Mossack Fonseca law firm did not assist a client in breaking any tax, anti-money-laundering, or other kind of law. What it did do, however, is to greatly abet the underpayment of taxes by wealthy people in a country, not beyond what they are required by law to pay, but what they ought to be required by a decent scheme of distributing social benefits and burdens. The criticism of the law firm would be that it is reinforcing an unjust distribution of resources, but of course the law firm (and its clients) would respond that what is just or unjust regarding a nation's fiscal policy is contestable. The law does not merely coordinate or clarify pre-existing moral obligations, because there is no prelegal position (and certainly no consensus on what that position would be) regarding the tax liabilities of wealthy owners of overseas property. Instead,

${ }^{137}$ Id. at 1341-42; see also Hershovitz, supra note _ , at 1193 n.54 (“[W]e can talk about what the law requires; it’s just that when we do, we are making moral or prudential claims.”).

${ }^{138}$ Id. at $1311-16$.

139 Id. at 1304.

${ }^{140} \mathrm{Id}$. at $1312-13$.

${ }^{141}$ Id. at 1314.

${ }^{142}$ See RAZ, supra note _, at 17. 
the law establishes a distinctive legal obligation to pay a certain amount of taxes, and no more.

From the legal point of view, what the firm did was permissible. Of course, the objection immediately follows: That may be true of legal permissibility, but it says nothing about moral permissibility. The law is one thing, morality another, and as Hart noted in his critique of Radbruch, it is a mistake to infer from the existence of a norm as law to a conclusion that it ought to be obeyed. ${ }^{143}$ Hart is correct, but a subtle point regarding the moral value of a distinctive domain of legal obligation is often overlooked. From the point of view of a political community, there may be moral value in establishing a framework of norms that purport to obligate citizens (or permit them to do things), with the further qualification that ascertaining the content of those norms does not require re-engaging in the moral reasoning they are intended to supersede and replace. Scott Shapiro, who is quite explicitly a positivist about the nature of law, defends the Moral Aim Thesis as part of his planning theory of law. ${ }^{144}$ A community faces a moral problem when its members desire to engage in cooperation, private ordering, and other modes of planning but are prevented from doing so by pluralism and disagreement, as well as the complexity of the issues that need to be addressed. The law has the moral aim of rectifying the moral deficiencies of a community beset with uncertainty and disagreement; it does so by providing the resources that enable citizens of a community to make and enforce binding commitments to one another. In order to provide leverage out of the "circumstance of legality," 145 the law must settle normative controversy by guiding conduct through authoritative norms, in the name of the community as a whole, the content of which can be determined without going back to the considerations about which people disagreed in the first place. ${ }^{146}$ The crucial insight here is that there is moral value to doing things in this way. The social fact of legal authorization to $\varphi$, within a community in which legality has moral value, gives citizens a reason in favor of $\varphi$ 'ing, although of course they may have other reasons not to $\varphi$.

Greenberg is willing to concede that the moral obligation brought about by the actions of a legal official may apply even when the arrangement

143 H.L.A. Hart, Positivism and the Separation of Law and Morals, 71 HARV. L. REV. 593, 618 (1958).

${ }^{144}$ SHAPIRO, supra note _, at 213-17; see also id. at 382 (stating clearly his commitment to legal positivism as rooted in social facts).

${ }^{145} \mathrm{Id}$. at $170-73$.

${ }^{146} \mathrm{Id}$. at 201-03; see also id. at 398 ("the logic of planning is respected only when the process of legal interpretation does not unsettle those questions that the law aims to settle"). 
thereby created is seriously morally flawed. ${ }^{147}$ Democratic considerations, plus considerations of salience, ex ante predictability, and preventing freeriding, may come together to create a reason of sufficient weight to $\varphi$ when required by legal institutions, even if $\varphi$ 'ing would not be the best course of action in the absence of the directive of a legal official. But it seems to me that these matters of weighing reasons are vulnerable to the pervasiveness of moral pluralism and conflict. Greenberg says the law creates an all-thingsconsidered obligation, not a pro tanto obligation. ${ }^{148}$ But this only occurs if democratic considerations, along with other factors, are sufficiently weighty relative to the moral reasons for the contrary action. This kind of retail level, case-by-case balancing of reasons seems likely to devolve into intractable disagreement about the relative priority of considerations on each side. It would be better to view the law as serving as a source of a distinctive type of reason that may be offered in justification of one's actions, as against normative criticism. In the Panama Papers example, the lawyer is offering the tax laws of her jurisdiction, along with related legal norms such as criminal prohibitions on money laundering, as an explanation of why she assisted the client in structuring a transaction in a particular way. Whatever one thinks of the morality of the client's conduct, the transaction is lawful, and that counts for something in the evaluation of the lawyer's decision to assist the client. It is not yet a full-on moral permission to do something, because of course there are plenty of lawful but morally rotten things one can do, and it may be wrongful to assist others in doing them. ${ }^{149}$ But I do think there is something that can be said in moral terms for giving reasons that refer to a distinctive kind of obligation created by the law and the legal system of a society. The following section explains why rational moral agents may adopt the point of view of the political community when giving reasons in justification of actions that affect others members of the community.

\section{RAtionAl AgENCy, PRACTICAL REASONING, AND LEGALiTy}

\section{A. Hobbesian and Rawlsian Conceptions of Public Reason}

The task of connecting a model of legal advising, jurisprudence, and political theory begins with the conception of the person and social cooperation that must be maintained in a democratic culture. ${ }^{150}$ On the

${ }^{147}$ Greenberg, supra note _, at 1314-15.

${ }^{148} \mathrm{Id}$. at 1306-07.

149 See APPLBAum, supra note _ (giving the extended example of Charles-Henri Sanson, the executioner of Paris under both Louis XIII and various Revolutionary governments).

150 See Rainer Forst, Contexts of Justice: Political Philosophy Beyond 
basically Kantian picture of human dignity that underlies much modern political and legal theory, each person has a practical identity - "a description under which you value yourself, a description under which you find your life to be worth living and your actions to be worth undertaking." 151 This subjective point of view is at the center of our conception of human dignity. ${ }^{152}$ Having dignity means having a story to tell, ${ }^{153}$ or to put it differently, a reflective self-consciousness that consists in having reasons to act and to live. ${ }^{154} \mathrm{~A}$ moral agent is a rational creature, that is, one who has the "capacity to recognize, assess, and be moved by reasons." 155 From the standpoint of reflective self-consciousness, people can endorse and act upon reasons. We recognize this capacity in ourselves and in others. Moral obligation comes from the recognition that others share with us the nature as creatures with a practical identity. ${ }^{156}$ The value of human dignity requires that people be given an opportunity to endorse or reject the reasons for treating them in a particular way.

Human beings are capable of assessing reasons and justifications, and proper respect for their distinctive value [i.e. for human dignity] involves treating them only in ways that they could, by proper exercise of this capacity, recognize as justifiable. ${ }^{157}$

For something to be a reason, on this view, means that it is something that others can adopt and follow. ${ }^{158}$ Justified actions are based on reasons we can share. ${ }^{159}$

Each of us has a practical identity and may justifiably demand that we be treated only in ways that we can accept. However, we all live alongside others in society, and our actions inevitably affect those around us. Not only do we have a practical identity as moral agents, related to the capacity to reflectively endorse reasons, we also have a capacity to see ourselves as free and equal

LIBERALISM AND COMMUNITARIANISM 175 (John M.M. Farrell trans. 2002) (1994).

${ }^{151}$ Christine M. KorsgaARD, The SourCes of Normativity 101 (1996).

152 David Luban, Lawyers as Upholders of Human Dignity (When They Aren't Busy Assaulting It), in LEGAL ETHICS AND HUMAN DIGNITY 65, 71 (2007).

${ }^{153}$ Luban, supra note _

${ }^{154}$ KORSGAARD, supra note _

155 T.M. SCANLON, WHAT WE OWE TO EACH OTHER 23 (1998).

156 KORSGAARD, supra note _, at 123.

157 SCANLON, supra note _, at 169.

158 Onora O’Neill, Vindicating Reason, in CONSTRUCTING AUTHORITIES: REASON, POLITICS AND INTERPRETATION IN KANT'S PHILOSOPHY 13, 28 (2015).

${ }^{159}$ Christine M. Korsgaard, The Reasons We Can Share: An Attack on the Distinction Between Agent-Relative and Agent-Neutral Values, in CREATING THE KINGDOM OF ENDS (1996). 
citizens of a political community, subject to impartially justified principles of justice. ${ }^{160}$ Because we recognize others as reasonable, free, and equal, we must propose fair terms of cooperation, which others may reasonably be expected to accept. ${ }^{161}$ In doing so, however, we run up against the fact of reasonable disagreement, arising from conflicts among basic values, the irreducibly different perspectives from which people view the world and understand the nature and end of human existence, disagreements about the weight and priority of various competing values, and empirical uncertainty. ${ }^{162}$ As Rawls notes, too, these are only the reasonable roots of what he calls the burdens of judgment. Disagreements also arise from the "prejudice and bias, self- and group interest, blindness and willfulness" which are familiar facts of political life. ${ }^{163}$ The citizenship project, of finding fair terms of cooperation among free and equal citizens, appears doomed from the start by reasonable pluralism, even if no one in public life was acting in bad faith.

There are at least two responses to the problem of pluralism about values, goods, and rights. The first is broadly Hobbesian. ${ }^{164}$ From the observation that human beings are all roughly equal in the power to inflict harms upon one another, ${ }^{165}$ there follow two laws of nature: First, that people ought to seek peace; and second, that people ought to be willing to give up what they would otherwise have a natural right to, which is "all things." ${ }^{166}$ As a matter of self-interest, we transfer the rights we would otherwise have, to harm and exploit others, by making a mutual covenant to obey a common authority. ${ }^{167}$ But of course controversies may arise concerning the rights and duties that are owed among the parties to the covenant, and "unless the parties to the question covenant mutually to stand to the sentence of another, they are as

160 JOHN RAWLS, POLITICAL LIBERALISM 49-50, 77-78, 85 (1993). See also ForST, supra note _ contrasted with ethical identities rooted in conceptions of the good. Id. at 35-36, 181-83. Because this is not a standard distinction in English-language political philosophy, and one that Rawls alludes to but does not employ systematically, I will not maintain it here.

161 RAWLS, supra note _, at 53-54, 81.

162 Id. at 55-57.

163 Id. at 58.

164 Thomas HobBes, Leviathan (Edwin Curley ed. 1994) (1668); see also Luciano Venezia, Hobbes' Two Accounts of Law and the Structure of Reasons for Political Obedience, 13 Eur. J. Pol. ThEORY 282 (2014); David Gauthier, Hobbes: The Laws of Nature, 82 PAC. PHIL. Q. 258 (2001); Kinch Hoekstra, Hobbes and the Foole, 25 POL. THEORY 625 (1997).

165 Hobbes, supra note _, Ch. XIII, at 74-75.

${ }^{166}$ Id., Ch. XIV, at 80.

${ }^{167}$ Id. at 82. 
far from peace as ever." ${ }^{168}$ On the analogy of an arbitrator resolving disputes among the parties, Hobbes imagines that the citizens of a commonwealth defer their judgment concerning rights to the sovereign, whose position on the matter then becomes a reason for all of those subject to the sovereign's authority. Citizens of the commonwealth "reduce all their wills, by plurality of voices, unto one will ... and acknowledge [the sovereign] to be author of whatsoever . . concern the common peace and safety." 169 In the place of a cacophony of competing views about rights and justice, there is now only the sovereign's view - one will - which now stands in for the will of the subjects of the sovereign.

On Hobbes's own view, obedience to the social contract is compelled by "the terror of some punishment greater than the benefit that [parties] expect by the breach of their covenant." ${ }^{\prime 70}$ That position does have the advantage of avoiding reliance on dubious psychological premises such as a motivation to internalize and act upon the requirements of law. ${ }^{171}$ It does so, however, at the cost of narrowing the practical identity of citizens to the desire to avoid sanctions. We ought to keep covenants because it would be in our self-interest to do so. ${ }^{172}$ Hobbes has a methodologically individualist conception of the domain of the social. It has no room to recognize reasons given from the point of view of each member of the political community, except insofar as everyone has a reason to yield his or her will to that of the sovereign. While the fear of sanctions certainly has a role to play in maintaining order, a conception of society, and hence an account of legal reasoning, that reduces all reasons to the desire to avoid sanctions is too thin. It has no room for the recognition by citizens that they exist in a community alongside others who, like themselves, are entitled to respect as reasoning agents and bearers of dignity.

Therefore, the second answer to the question of finding common ground among disputatious yet sociable creatures ${ }^{173}$ relies not on coercion but on the demand for a reasonable justification of one's actions in the context of a society of reasonable, free, and equal citizens. On this Rawlsian approach,

${ }^{168} I d$., Ch. XV, at 98.

${ }^{169}$ Id., Ch. XVII, at 109.

${ }^{170} I d$., Ch. XV, at 89.

171 See Frederick Schauer, The Force of LAW 43-48 (2015) (questioning the plausibility of H.L.A. Hart's "puzzled man" who seeks to know what the law requires in order to conform his behavior to it).

172 See Hoekstra, supra note

173 J.B. SCHNEEWIND, THE INVENTION OF AUTONOMY: A History OF MODERN MORAL PHILOSOPHY 71-72 (1998) (citing Hugo Grotius's recognition of this fact about human nature as one of the distinctively modern insights in moral philosophy). 
reasonableness, as a political ideal of democratic citizenship, ${ }^{174}$ requires justification of fair terms of social cooperation from a suitably constructed social point of view which all can accept. ${ }^{175}$ Reasonable citizens of a democratic society share in the process of collective self-determination. ${ }^{176}$ The reasons underlying the principles of social cooperation are reciprocal and generally shareable, ${ }^{177}$ but are distinct from the reasons that apply to people in pre-political contexts. The domain of the political is therefore subject to freestanding conceptions of justice and legitimacy. ${ }^{178}$ Political principles of fair cooperation claim objectivity from "the perspective of public, reciprocal, and general justification between reasonable, free, and equal persons." ${ }^{179}$ For Rawls, the justification based on public reasons is aimed at working out a political conception of justice underlying the basic structure of the political institutions of a society. ${ }^{180}$ The argument presented here is intended as Rawlsian, though not with strict fidelity to Rawls's own position. The political-moral conception of citizenship does not have to be limited to individuals in the hypothetical position of designing the basic political institutions of a constitutional democracy. Citizens are involved in assessing not only the justice of the basic structure, but the legitimacy of political decisions made by officials acting within their prescribed institutional roles.

For Rawls, public reason is to be deployed "when constitutional essentials and matters of basic justice are at stake." ${ }^{181}$ Once those issues are settled, he has less to say about the reasons citizens should be prepared to offer one another when a matter of contention arises among them. The constitution establishes just political procedures (the justice of which are assessed by public reason), but then Rawls pretty much leaves it up to those procedures to work out the solutions to more micro-level issues that may arise in the common life of citizens of the political community. ${ }^{182}$ There are many subconstitutional matters on which a citizen may face the need to bring her

${ }^{174}$ RAWLS, supra note _, at 62.

${ }^{175}$ FORST, supra note _, at 181-82.

${ }^{176}$ RAWLS, supra note _

${ }^{177}$ FORST, supra note _, at 185.

${ }^{178}$ RAWLS, supra note _

${ }^{179}$ FORST, supra note _

${ }^{180}$ RAWLS, supra note __, at xl-xliii. Thanks to Gregg Strauss for reminding me of the limitations of Rawls's position and the need to clarify that my argument is an extension of Rawls's views.

${ }^{181}$ Id. at xlix; see also WALDRON, supra note __, at 151-61 (noting Rawls's silence on whether the burdens of judgment apply to political decisions made within the basic constitutional structure justified by public reason).

182 RAWLS, supra note _ , at 337-39 (describing how the constitution specifies a just political procedure and incorporates restrictions protect basic liberties, and this is based on public reason, but then "[t]he rest is left to the legislative stage”). 
reasons into accord with the reasons of others. ${ }^{183}$ Rawls does not say explicitly that the legitimacy of a decision reached by institutional procedures is subject to evaluation using public reason. ${ }^{184}$ But the force of his burdensof-judgment argument applies to the legitimacy of sub-constitutional decisions as well. When we disagree with others but nevertheless seek to cooperate on common projects, we need a way to deal with one another respectfully, despite our disagreements. We do this by offering reasons that others may reasonably accept, accepting that the addressee of our reasons is a free and equal citizens of our political community. There is something deeply respectful about finding a reason for something in a reason that another can accept as well. ${ }^{185}$ The law provides a resource for offering reasons that others can share. Given the already-existing constitutional structure, it is likely that these reasons will make reference to decisions made by political officials acting within their constitutional roles as law-makers and law-interpreters.

To sum up: Human beings are characterized by the capacity to assess and endorse reasons. Human dignity requires treating others in accordance with this capacity. As citizens of a political community, we owe each other a justification based on reasons others can understand and share. However, we disagree about many things, and do so reasonably. How might a government treat citizens with dignity, while also recognizing the need to move beyond controversy and get things done, consistent with the burdens of judgment? One of the most important insights of recent political-legal theory, as distinguished from the kind of "pure" jurisprudential scholarship that is concerned mostly with the nature of the concept of law, is that we can make more progress asking "what is good about law?" rather than the more traditional question "what is law?" Law can be seen as a way of governing a community of self-determining moral agents. ${ }^{186}$ It manifests respect for the human dignity of citizens. Law is, on this view,

a mode of governance that takes people seriously as dignified and active presences in the world - persons with lives of their own to lead, with points of view about how their lives relate to the interests of others, and

183 Charles Larmore, Public Reason, in ThE CAMBridge COMPANION TO RAWLs 368 (Samuel Freeman ed. 2003).

184 WALDRON, supra note _, 153 (concluding that "the idea of public reason is incompatible at most with the existence of reasonable disagreement about the fundamentals of justice" but that it "is not incompatible with reasonable disagreement about the way the details are worked out”).

185 Larmore, supra note _, at 370.

186 David Luban, Natural Law as Professional Ethics: A Reading of Fuller, in LEGAL ETHICS AND HUMAN DIGNITY 110-11, 127 (2007). 
with reason and intelligence to exercise in grasping their society's system of order." 187

Most importantly, the rule of law - lawful governance - contrasts with the exercise of raw power. ${ }^{188}$ Waldron gets it exactly right when he says "[r]uling by law is quite different from herding cows with a cattle prod or directing a flock of sheep with a dog." ${ }^{189}$ Governors in a rule-of-law society must aspire to connect with the rational agency of their subjects, rather than simply punishing or terrifying them into obedience.

From this conception of the value of law flows the familiar formal criteria that characterize the rule of law and differentiate it from other forms of governance, such as the generality and prospectivity of norms. ${ }^{190}$ The best known analysis of legality in formal terms is Lon Fuller's. Fuller illustrated the virtue of the rule of law with an amusing parable of a decent but clueless ruler named King Rex. Rex really wanted to "make his name in history as a great lawgiver," 191 but his attempts at making law were repeatedly thwarted by his failure to attend to the formal qualities that made law distinctive and valuable as a mode of governance. For example, he decided cases one at a time without concern for whether there were principles that explained why one case was treated differently from another. Rex drafted a legal code, but kept it locked away in a box in his bedroom. When he finally released a public version of his code, it was so badly drafted and obscure that even professional lawyers could not make heads or tails of it. Then his code became a moving target as he undertook to revise it frequently enough to keep pace with changing circumstances. In the end the well-intentioned Rex's efforts to make law only created chaos, but the reader is left with a sense of foreboding to learn that "[t]he first act of his successor, Rex II, was to announce that he was taking the powers of government away from the lawyers and placing them in the hands of psychiatrists and experts in public relations." 192

${ }^{187}$ Waldron, supra note _, at 40.

188 See Hanoch Dagan, The Realist Conception of Law, 57 U. TORONTO L.J. 607, 623 (2007) ("reason imposes real - albeit elusive - constraints on the choices of legal decision makers and thus on the entailed application of state power").

${ }^{189}$ Waldron, supra note _, at 26-27.

190 See, e.g., FinNis, supra note _, at 270-76; TOM BINGHAM, THE RulE OF LAW 49-50 (2010); Joseph Raz, The Rule of Law and Its Virtue, in THE AUTHORITY OF LAW 210-29 (1979); Robert S. Summers, Principles of the Rule of Law, 74 NOTRE DAME L. REV. 1691 (1999). Fuller's list, for example, comprises eight criteria: (1) generality, (2) promulgation, (3) prospectivity, (4) clarity, (5) consistency, (6) feasibility (not requiring what impossible), (7) stability, and (8) congruence between law and official action. LON L. FULLER, THE MORALITY OF LAW 46-90 (rev’d ed. 1964).

191 FULLER, supra note , at 34 .

192 Id. at 38. 


\section{B. How the Political-Moral Value of Legality Constrains Legal Reason- Giving}

For Fuller, the point of the Rex story is the irony that a ruler might set out to do the right thing by his subjects but end up making things worse by failing to respect the form of governance by law. Influenced by important and somewhat under-appreciated recent work on Fuller by Jeremy Waldron and David Luban, I want to take the story in a slightly different direction by focusing on the relationship between legality and the dignity and selfgoverning agency of citizens. ${ }^{193}$ This is a theoretical account of a particular domain of practical reasoning. Whenever anyone acts in a way that interferes with the interests of others, he or she owes the other a reasoned justification, appealing to considerations that the affected person can accept. In a complex society, however, everyone is always bumping up against the interests of others. Moreover, in a pluralist society, the burdens of judgment create a further difficulty, stemming from the reasonableness of much normative and empirical controversy. ${ }^{194}$ As moral agents, we owe reasons to those affected by our actions; as citizens, we owe political reasons to other free and equal citizens. "The important moral values of reciprocity and respect for autonomy are expressed in the institutional framework of the rule of law." ${ }^{195}$ Working within the institutional framework of the rule of law, in turn, imposes requirements of reasonableness on participants, including judges and lawyers. Only a reasoned justification, making reference to the right kinds of reasons, would count as legitimate in a democracy.

At the risk of adding yet another laundry list of rule-of-law virtues, ${ }^{196} \mathrm{I}$ argue that legal reasons - those that count in favor of a conclusion of law should aspire to possess the following features:

1. Relational. Legal reasons must be the sort of reasons affected persons can endorse. Respecting human dignity means responding to others as "a locus of reasons." ${ }^{197}$ When our actions affect others, we owe

193 See id. at 162. Waldron and Luban both cite this passage as central to Fuller's moral conception of legality. See Luban, supra note _, at 110; Waldron, supra note _, at 27-28. See also Colleen Murphy, Lon Fuller and the Moral Value of the Rule of Law, 24 L. \& PHIL. 239 (2005).

194 RAWLS, supra note _, at 55.

195 Murphy, supra note _

196 See Jeremy Waldron, The Rule of Law and the Importance of Procedure, in NomOS L: GetTiNG TO THE Rule OF LAW 3, 5-7 (James E. Fleming, ed., 2011) (summarizing "laundry list" approaches to defining the rule of law).

197 SCANLON, supra note _, at 105. 
them a reason they can accept from the point of view of those things they value.

2. Political. Legal reasons are established in the name of society as a whole. They relate to a shared project within a political community of working out a common scheme of norms to govern interactions among citizens, and with the state. Legal reasons pertain to the norms worked out by legitimate processes for resolving disagreements over values, rights, and justice. It should be possible to make legal arguments without re-engaging in the underlying debates that the law was intended to resolve. ${ }^{198}$

3. Practical. Legal reasons are practical reasons. That means they count in favor of a conclusion regarding what one ought to do, or is prohibited from doing. Relatedly, they are normative - legal reasons bear directly on what one has reason to do, and are not merely a heuristic enabling better predictions of the application of sanctions.

4. Systematic. Because the law assumes that its subjects can grasp and apply it to their conduct, bits and pieces of the law must be related to one another in a coherent, intelligible way. ${ }^{199}$ The systematicity of law is one safeguard against whimsical or even tyrannical decisions by holders of official power. But legal reasoning also aspires to be principled. Arbitrary or ad hoc judgments are at least less likely to satisfy the first two criteria of appealing to reasons that affected persons can endorse and standing for a position established in the name of the political community as a whole. ${ }^{200}$

198 SHAPIRO, supra note _, at 348.

199 See Jeremy Waldron, Thoughtfulness and the Rule of Law, 18 BRIT. ACAD. REV. 1, 7-8 (2011) ("The norms administered in our legal system may seem like just one damned command after another, but lawyers and judges try to see the law as a whole; to discern some sort of coherence or system, integrating particular items into a structure that makes intellectual sense.”).

200 This criterion bears an obvious relationship to Ronald Dworkin’s argument for the virtue of integrity and its necessary relationship with the legitimacy of political decisions. See RONALD DWORKIN, LAW's EMPIRE 178-215 (1986). I think Dworkin is on the right track in believing that the most plausible account of political obligation is associative - that is, related to recognition that citizens are united by membership in a political community and thus owe each other special obligations of reasonableness, reciprocity, and fair dealing. See id. at 198-99, 205. The underlying political ideal that "each person is as worthy as any other [and] must be treated with equal concern” is spot-on. Id. at 213. But Dworkin draws too strong a negative conclusion that a political community cannot support compromises among competing viewpoints, but must instead seek a coherent, common underlying scheme of principles. See id. at 211-12. Fairness and equal respect may support a system of law-making 
5. Public. Even if only hypothetically, legal reasons are those that could be offered as an explanation to a suitably well-informed observer. As in Fuller's Rex story, secret law is a contradiction in terms. Legal reasons are those that are addressed not only to affected persons but to other members of the political community, whose law they reflect.

This list is meant to specify at a middle level of generality an account of legal interpretation as a craft or a disciplined practice of reason-giving. ${ }^{201}$ The

that accepts logrolling, horse-trading, and other familiar tools of legislation that allow a political community to settle controversies that may not be capable of principled resolution due to pluralism and disagreement within the community.

${ }^{201}$ I have referred to the craft of legal reasoning on several occasions. See, e.g., WENDEL, supra note —, at 184-85; W. Bradley Wendel, The Craft of Legal Interpretation, in INTERPRETATION OF LAW IN THE AGE OF ENLIGHTENMENT: FROM THE RULE OF THE KING TO THE RULE OF LAW (Yasutomo Morigiwa ed. 2011). In the legal process tradition, the idea of craft is associated with Cardozo, Llewellyn, and Edward Levi. See KARL N. LLEWELLYN, THE COMMON LAW TRAdiTION (1960); EdWARD H. LEVI, AN INTRODUCTION TO LEGAL REASONING (1949); BENJAMIN N. CARDOZO, THE NATURE OF THE JUdiCiAL PROCESS (1921); see also PostemA, supra note _ , at 132-36 (situating the notion of craft within American jurisprudence, particularly realism and the legal process school); DUXBURY, supra note _, at 217-19 (taking a more skeptical approach to the craft of legal reasoning). Ben Zipursky, a sympathetic but rigorous reader, has argued that my use of the idea of craft risks turning into a natural law, or at least Dworkinian, theory about the nature of law, and that I painted myself into that corner by uncritically accepting Hart's social-facts positivism. See Benjamin C. Zipursky, Legal Positivism and the Good Lawyer: A Commentary on W. Bradley Wendel's Lawyers and Fidelity to Law, 24 GEO. J. LEgAL ETHICs 1165, 1174-75 (2011) ("one cannot separate the question of what the best interpretation of the law is, from the question of which justification of the law would place it in its best light, from a normative point of view"). Zipursky suggests I ought to "reject the sharpness of Haitian positivism . ..., to accept the role of values in legal craft, and to maintain [my] overall view of the lawyer's proper role." $I d$. at 1178. In doing so, however, I do want to remain faithful to positivism in some form, given the pluralism, settlement, and coordination story that is at the center of this theory. The answer, suggests Zipursky, is to locate the morality of law and the lawyer's role in the right place:

What is important, for Wendel, is not the question of whether there is a moral aspect to legal interpretation. What is important is that it is (in principle) possible for lawyers to identify which interpretations are plausible and which are not, and to do so in a manner that takes the legal system's and the particular law's values and moral and political decisions seriously.

Id. at 1179. The emphasis here on the political-moral value of the rule of law, and the constraint it supplies on legal interpretation, is an attempt to hang on both to legal positivism and a normative account of legal advising that responds appropriately to the Holmesian bad man style of interpretation that characterizes one version of the standard conception. Doing so requires bringing Fuller, who was always in the background of my approach to the lawyer's role (hence the title of the 2010 book) more into the foreground. 
basic idea is that law is a purposive human activity. People (and entities advised by people) who are the subjects of the law must be capable of being guided by it. That is not necessarily to say that the law creates moral reasons for doing, or refraining from doing, something. ${ }^{202}$ But the reasoned nature of guidance by law does require that human subjects be capable of grasping the meaning of a would-be legal norm and acting on it. ${ }^{203}$ If the law prescribed something nonsensical, or impossible, it would be futile to expect its subjects to comply with it. To provide guidance to rational agents, the law must be something which one may make sense of, as aiming at some rational end. To provide guidance to rational agents about what they ought to do as citizens of a political community, bound to respect the inherent dignity of other citizens, the law must address the predicament of people trying to work out a common scheme of norms. Law rightfully obligates - that is, it is legitimate - when it represents a principled elaboration of a social problem and its solution. ${ }^{204}$ Legitimate law must stand in for reasons that people would actually have and be able to cite as a justification for their actions when they affect the interests of others. Legal reasoning must therefore make sense of the application of law to specific social problems in light of underlying principles of the political community's mutually agreed-upon resolution of the problems.

Many legal philosophers believe Fuller was fundamentally confused to refer to a similar list of features as the "inner morality of law." ${ }^{205}$ Legal positivists insist that the nature of law is one thing, and its justice or injustice another; similarly, whether there is an obligation to obey the law is a separate question from whether the law requires some action. ${ }^{206}$ It is arguable that, despite his reputation as the grandfather of social-facts positivism, H.L.A. Hart was less committed to the existence of settled meaning within law than to a view of legality as a "disciplined practice of public practical reasoning." ${ }^{207}$ Understood in that way, there may not be that much daylight

\footnotetext{
${ }^{202}$ See Postema, supra note _, at 293; Donald C. Langevoort, Someplace Between Philosophy and Economics: Legitimacy and Good Corporate Lawyering, 75 FoRDHAM L. REV. 1615 (2006).

${ }^{203}$ Waldron, supra note _, at 27.

${ }^{204}$ HART \& SACKS, supra note _ , at 147-50.

${ }^{205}$ See SHAPIRO, supra note —, at 394 (observing the notoriety surrounding Fuller's claim that the eight criteria of legality constitute a morality of law); Jeremy Waldron, Positivism and Legality: Hart's Equivocal Response to Fuller, 83 N.Y.U. L. REV. 1135 (2008) (surveying the Hart-Fuller debate and giving a more sympathetic account of Fuller's project).

${ }^{206}$ See, e.g., H.L.A. Hart, Positivism and the Separation of Law and Morals, 71 HARV. L. REV. 593 (1958).

${ }^{207}$ Gerald J. Postema, Positivism and the Separation of Realists from Their Skepticism: Normative Guidance, the Rule of Law, and Legal Reasoning, in THE HART-FulLER DEBATE IN THE TwENTY-FIRST CENTURY 259, 260 (Peter Cane ed. 2010).
} 
between Hart's position and Fuller's views in The Morality of Law. Both Fuller and Hart appreciated the moral value of governing a political community using processes that respected the rational agency of citizens. Hart may have been influenced by his exposure to then-current legal process ideas which held that law is "a dynamic, social enterprise, not a static system of rules," 208 and it is distinguishable from the assertion of naked power, preferences, or interests, and from arbitrary decisionmaking. Maybe it is possible to construct a kind of Hart 2.0, animated more by legal-process values than the methodological commitment to social facts as the foundation of law. ${ }^{209}$ That is not my concern, however. Whether Hart would have endorsed this view, all that is needed to realize Fuller's vision of a society of free and equal citizens governed by the rule of law is a normative account of legal advising that requires law-interpreters and law-appliers - that is, lawyers - to be committed to a disciplined practice of reason-giving.

Legal advising is aimed at constructing a legal justification for the course of action proposed by the client. It calls for the exercise of a disciplined craft of legal reasoning. ${ }^{210}$ But it does not require that the interpreter arrive at a uniquely determined “one right answer” to a legal question. Ronald Dworkin, postulated that there is a single answer to a correctly formulated question concerning a political community's law on point (formulated, that is, to include the scheme of political-moral principles that underlies positive law); the position defended here is compatible with a wide range of views about what the right legal answer might be. A legal justification may be reasonable, but it need not be right. Although this is a theory of advising, located within the domain of professional ethics, its point of reference is not the common good or the public interest, about which reasonable people may disagree. The law aims at a social settlement, but it is dynamic and contestable. The settlement created by law is something within which legal argumentation may take place; it is not a conversation-stopper. Finally, while the position defended in this Article is considerably influenced by legal process scholars like (Henry) Hart and Sacks, it seeks to shed some of the baggage of the legal process school. ${ }^{211}$ So, for example, while it was important to Herbert Wechsler to differentiate value-neutral legal reasoning from supposedly unprincipled assertions of extra-legal values, ${ }^{212}$ legal advising on my view

208 Stone, supra note _ _, at 715 (punctuation and emphasis slightly altered) (describing position of legal-process theorists Henry Hart).

${ }^{209}$ See Zipursky, supra note __, at 1174-79.

210 See HART \& SACKS, supra note _, at 156-57.

${ }^{211}$ For more on this effort see Section IV, infra.

212 See Herbert Wechsler, Toward Neutral Principles of Constitutional Law, 73 HARV. L. REV. 1 (1959). For a critique of Wechsler's distinction between principle and policy, see Gary Peller, Neutral Principles in the 1950's, 21 U. MICH. J.L. REFORM 561 (1988). 
may include contestable values, as long as they bear the right kind of relationship with the community's law. Wechsler is correct to insist that legal argumentation differs in kind from the assertion of raw power, but he was wrong to believe that an appeal to values cannot be an effort to justify an action to others, in terms they can endorse. Law is not separate from politics, but a means of governing a community in a way that is respectful as possible of citizens as free and equal.

To make this more concrete we can return to the examples discussed in Section I, in which lawyers have been criticized for advising clients on conduct that is perceived to be somehow inconsistent with the community's law or values. What can we say, from the point of view of legal interpretation as a disciplined practice of reason-giving, about the Enron transactions or tax shelters, the Panama Papers, the Torture Memos, the Rosenstein memo, or other high-profile cases of controversial legal advising?

Start with the Rosenstein memo. Numerous observers criticized the Deputy Attorney General for supplying a veneer of legality for a decision that was pre-cooked and based on political considerations. ${ }^{213}$ It is clear, however, that the President had at least de facto power, and almost certainly also lawful authority, to fire F.B.I. Director Comey. ${ }^{214}$ Rosenstein advised only that the President could do what he was authorized to do. Given that, how could there be any coherent critique of his legal advising? The answer is that ethical legal

${ }^{213}$ See, e.g., Benjamin Wittes, Et Tu Rod? Why The Deputy Attorney General Must Resign, LAWFARE (May 12, 2017) ("Trump had used his deputy attorney general as window dressing on a pre-cooked political decision to shut down an investigation involving himself, a decision for which he needed the patina of a high-minded rationale.”); Bob Bauer, How It Was Done: The Problem Is Not Only That Trump Fired Comey, But How He Did It, LAWFARE (May 10, 2017) (noting the haste with which Rosenstein acted, suggesting that the reasons given in the memo are pretextual). Subsequent disclosure of a draft letter written by Trump and political advisor Stephen Miller further supports the conclusion that Rosenstein's purported legal advice was nothing more than window dressing. See Michael S. Schmidt \& Maggie Haberman, Mueller Has Early Draft of Trump Letter Giving Reasons for Firing Comey, N.Y. TIMES (Sept. 1, 2017).

${ }^{214}$ The President appoints the Director of the F.B.I., with the advice and consent of the Senate, for a ten-year term. See 28 U.S.C. § 532 \& Note (citing Pub. L. 90-351, title VI, $\S 1101$, June 19, 1968, 82 Stat. 236, as amended by Pub. L. 94-503, title II, § 203, Oct. 15, 1976, 90 Stat. 2427; Pub. L. 112-24, § 2, July 26, 2011, 125 Stat. 238). This Congressional action was in response to the 48-year term of office of F.B.I. Director J. Edgar Hoover. See CONGRESSIONAL RESEARCH SERVICE, FBI Director: ApPoinTMENT AND TENURE (Feb. 19, 2014), available at https://fas.org/sgp/crs/misc/R41850.pdf. Congress did not include language requiring that the President remove the F.B.I. Director only "for cause," or some similar limitation. Notably, President Clinton removed William Sessions from the position in the middle of Freeh's ten-year term. See David Johnston, Defiant F.B.I. Chief Removed from Job by the President, N.Y. TIMES (July 20, 1993). 
advising is not merely a matter of getting the right answer to a client's question, “Can I do this?” Rather, the ethics of legal advising supply criteria that can be used to evaluate the reasons given in support of a conclusion of law. A legal-process critique of the Rosenstein memo would contend that it was not a candid, independent analysis of the law but a mimicry of the form and process of legal advising. The truth of the matter is that Trump wanted to shut down the investigation for political reasons, as he himself admitted astonishingly, in a conversation with Russian officials. ${ }^{215}$ Rosenstein was thus left in the position of purporting to offer legal advice based on the careful, impartial weighing of a factual record and legal considerations on both sides, when in fact all he did was recount a series of episodes surrounding Comey's investigation, during the 2016 presidential campaign, of Hillary Clinton's handling of classified emails. ${ }^{216}$ Former high-ranking government officials did, in fact, opine that Comey's conduct was improper. ${ }^{217}$ But the time to dismiss Comey for those actions would have been soon after Inauguration Day, not when the investigation into Russian interference with the election was starting to heat up.

On the legal-process account of ethical legal advising, the Rosenstein memo fails the test of whether it can be understood as reasons given to a rational agent, capable of assessing these considerations and acting on them. At one level the memo is simply deceptive, stating that the reasons counting in favor of the action are $X$, when in fact they are $Y$ and $Z$. The practice of reason-giving requires at least a threshold level of trust and sincerity. That is not to say that a reason given as a legal justification must necessarily be the reason that motivates the action. A speaker may wish to provoke and outrage and audience, and may cite the First Amendment protection for robust, uninhibited, wide-open public debate as a reason he should not be punished for his speech. ${ }^{218}$ A lawyer advising the speaker may state that the speech is lawful based on the constitutional principle, even if neither the lawyer nor the client cares about fostering open debate. But the First Amendment principle at least has something to do with the reason that the speaker is not subject to

215 The day after the firing, Trump reportedly told Russian officials that he fired the "nut job” Comey to take pressure off the investigation. See Matt Apuzzo, Maggie Haberman \& Matthew Rosenberg, Trump Told Russians That Firing 'Nut Job' Comey Eased Pressure From Investigation, N.Y. TIMES (May 19, 2017).

${ }^{216}$ For the text of the memo, see, e.g., Rod Rosenstein's Letter Recommending Comey be Fired (May 10, 2017), available at http://www.bbc.com/news/world-us-canada-39866767

217 See, e.g., Eric Holder, James Comey is a Good Man But He Made a Serious Mistake, WASH. PosT (Oct. 30, 2016); Jamie Gorelick \& Larry Thompson, James Comey is Damaging Our Democracy, WASH. Post (Oct. 29, 2016).

218 See Harry Kalven, Jr., "Uninhibited, Robust, and Wide-Open”: A Note on Free Speech and the Warren Court, 67 MiCH. L. REV. 249 (1968). 
legal penalties. It bears on the legal permissibility of the action in the right way, notwithstanding the actor's actual motives. The Rosenstein memo exhibits a different kind of insincerity. It treats the reader not as a free and equal citizen and a reasonable agent, but as a sucker. In Harry Frankfurt's terms, the rhetoric of the memo is not even a lie, but bullshit - defined as "a description of a certain state of affairs without genuinely submitting to the constraints which the endeavor to provide an accurate representation of reality imposes." 219 A reasoned justification is addressed to someone who presumably wishes to evaluate the offered reasons, to determine whether they are considerations that the addressee can endorse. The justification also refers to public reasons, that can be endorsed from the standpoint of what the political community has established as its framework for cooperation. A purported justification that in fact bears no relationship with considerations that actually count in favor of the action is an offense against legality as a reciprocal, social practice. ${ }^{220}$

In a sense, then, the Rosenstein memo is equivalent to Hart's famous illustration of the gunman demanding the victim's wallet. ${ }^{221}$ The gunman can make demands and back them with threats, but does not thereby create a genuine obligation. An obligation exists when our moral situation changes and there are rights and duties imposed on ourselves and others that are related to standards of behavior to be followed in society generally. ${ }^{222}$ The subjects of Fuller's memorable character King Rex were disposed to obey their monarch's reasonable directives, but they were frustrated because Rex's commands were so arbitrary, whimsical, and inscrutable that his subjects' powers of reasoning were sidelined. That left the subjects in the position of a flock of sheep responding to the barking and nipping of a herding dog, ${ }^{223}$ not having any means of directing themselves as responsible reasoning agents would ordinarily do. Coercion can occur through deception and manipulation as well as through physical force. ${ }^{224}$ It is undoubtedly the case that "[l]aw makes us do things we do not want to do,”225 to act against our interests, and

${ }^{219}$ HARRY FrANKFURT, ON BULLSHIT 32 (2005).

220 See WILLIAMS, supra note —, at 118-20 (locating the wrongfulness of lying in violation of reciprocity and the expectations of truthful exchange).

${ }^{221}$ HART, supra note _, at 19-20.

${ }^{222}$ Id. at 43-44.

${ }^{223}$ Waldron, supra note _, at 26-27.

224 See Sissela BoK, Lying: Moral ChOiCe in PubliC And Private Life 18, 22 (1978); see also James Boyd White, Heracles' Bow: Persuasion and Community in Sophocles' Philoctetes, in HERACLES' BOw: EsSAYS ON THE RHETORIC AND POETICS OF THE LAW 3 (1985) (understanding the wrongfulness of Odysseus's deception of Philoctetes as an offense against the dignity of Philoctetes but also against the interests of the community).

225 SCHAUER, supra note _, at 1. 
occasionally to submit to the threat of punishment for non-compliance. It is also true that some fairly awful nation-states, such as Haiti under "Papa Doc” Duvalier, enforce norms that their citizens acknowledge as law, even though these regimes have little claim to legitimacy beyond "raw power, more guns, and the imposition of fear." 226 My claim here is not that a high-ranking government lawyer could not write a memo stating that the President has the power to do something, that no other governmental institution can limit this power, and thus everyone else just has to lump it. Notably, however, that is not what Rosenstein did. He tried to give a legal justification for the President's action that appealed to the capacity for reasoning of those to whom it was addressed (presumably the members of the public who care about the President acting lawfully). Rosenstein tacitly accepted something like Fuller's criteria for giving a justification that counts as law, not merely the assertion of raw power.

Consider another example - this time, one of the transactions revealed by the Panama Papers, as described in the New York Times, of a wealthy American hedge fund manager who used a Panamanian charitable foundation to hold $\$ 134$ million in assets and transfer them to his children. ${ }^{227}$ For the purposes of this analysis, ignore the transnational legal issues and focus on the conduct of a hypothetical lawyer in the United States assisting the client with the transfer of assets. The transaction involved a "maze of companies," a nominally independent charitable foundation that was neither independent (its directors were law firm employees) nor involved in charitable causes, secret bank accounts, and dummy purchase orders to make it appear that money had been spent for business purposes. There are legitimate reasons people may want to keep their financial affairs secret. A political community may endorse those reasons and incorporate them into its governing law. Secrecy may be permitted for reasons such as desire for privacy and protection from being victimized by scammers. People also may want to

${ }^{226}$ Id. at 95-96. It is noteworthy that Schauer mentions Fuller only once, and very much in passing, in his book arguing for the centrality of coercion to law. Granted, Fuller is often treated as peripheral to debates in mainstream analytic jurisprudence concerning the nature of law. To the extent Schauer is concerned to establish the deficiency in a theory of the nature of law that overlooks the salience of coercion, it is understandable that he does not have much to say about Fuller. But for anyone who is concerned about the way in which getting a theory of law right matters for other purposes, such as specifying the ethical obligations of legal advisors, it is important to grasp the social value of law, and it is well worth paying attention to what Fuller has to say about the value of legality as a mode of governance that pays respect to the dignity of its subjects. In fairness, Schauer has written elsewhere about Fuller's attempt to demonstrate the normativity of law apart from coercion. See Frederick Schauer, Fuller's Internal Point of View, 13 L. \& PHIL. 285, 292-93 (1994).

227 See Eric Lipton \& Julie Creswell, Panama Papers Show How Rich United States Clients Hid Millions Abroad, N.Y. TIMES (June 5, 2016). 
create entities to hold assets for a variety of reasons, including capturing tax benefits that have some public purpose. At some point, however, the structure of secret accounts, artificial entities, and not-so-independent directors ceases to make sense as a rational response to a social problem, or even a nested set of problems, regarding the right of privacy and its limits, intra-family wealth transfer, and the like. Moreover, it would be difficult for a lawyer to give an explanation of these transactional forms that would align with the rationales that give coherence to the underlying legal doctrines. The sincerity of any explanation would also be suspect given the obvious motivation to employ the structure to avoid estate taxation.

The reaction of many observers to the Panama Papers disclosure was similar to the criticism of the Rosenstein memo. ${ }^{228}$ Here were elaborate simulacra of legal justifications, but in the end they were just smokescreens for the exercise of raw power by wealthy clients. With enough money, one can purchase sufficient secrecy and transactional complexity to reduce the likelihood of detection and punishment for tax fraud or money laundering to an acceptable degree. But that is not the same as a judgment that the legal treatment claimed for the transactions (whether as a matter of tax law, compliance with anti-money laundering provisions, or otherwise) is adequately supported by a reasoned justification. The Fuller-inspired criteria above provide an account of this intuition. The sense that there is something wrong with the transactions with offshore entities relates to the deficiencies of the proffered justification on the criteria of publicity, generality, systematicity, and sincerity.

This is not to say that lawyers can never make innovative use of legal tools that were designed for some other purpose. And it also does not rely on the assumption that there is only one purpose underlying the law on a given point. Mainstream techniques of statutory interpretation, at least in the United States, no longer maintain the legal fiction that they are seeking to uncover the intent of the legislature, but rather are interpreting the meaning of the statute. ${ }^{229}$ With the common law the case for any unique legal meaning is

${ }^{228}$ See, e.g., Editorial, The Panama Papers' Sprawling Web of Corruption, N.Y. TIMES (Apr. 5, 2016).

${ }^{229}$ See, e.g., John Manning, Constitutional Structure and Statutory Formalism, 66 U. CHI. L. REV. 685 (1999); Stephen Breyer, On the Uses of Legislative History in Interpreting Statutes, 65 S. CAL. L. Rev. 845 (1992); William N. Eskridge, Jr. \& Philip P. Frickey, Statutory Interpretation as Practical Reasoning, 42 STAN. L. REV. 321 (1990); William N. Eskridge, Jr., The New Textualism, 37 UCLA L. REV. 621 (1990); Frederick Schauer, Statutory Construction and the Coordinating Function of Plain Meaning, 1990 SUP. СT. REV. 231 (1990); Cass R. Sunstein, Interpreting Statutes in the Regulatory State, 103 HARV. L. REV. 405 (1989); Daniel A. Farber, Statutory Interpretation and Legislative Supremacy, 
even more doubtful, given competing lines of authority, precedents that are difficult to reconcile with each other, and the intrinsic indeterminacy of legal rules that take meaning only in relation to relevantly similar factual situations. It is misleading at best, disingenuous at worst, to talk about "the law" as having a univocal purpose. It is more helpful to think of the law as a toolbox or a set of resources for articulating reasons in justification of a course of action. But it is important not to overdo the toolbox metaphor, because even individual legal doctrines may have multiple purposes. For example, the use of the Panamanian charitable foundation to hold assets seems a bit fishy, given the assumed purpose for which that entity structure was recognized by Panamanian law. Recently, however, some attention has been focused on an entity structure called a foundation, or stichting, under the law of the Netherlands. A stichting is similar to the Panamanian foundations used by Mossack Fonseca in that it has no owners and is governed solely by a board of directors. A stichting may hold assets in trust or serve as the shareholder or general partner for special-purpose vehicles used in securitization transactions. Because stichtings separate ownership and control, they may be used to control assets while not recognizing ownership of the assets by an individual or corporation. The stichting structure was employed by pharmaceutical company Mylan as a takeover defense in its battle with Teva Pharmaceuticals. ${ }^{230}$

Should we criticize the use of a stichting to ward off a hostile takeover in the same way that we would look askance on the use of a Panamanian charitable foundation to hold the assets of a U.S. taxpayer? Maybe so. It would depend on the reasons given in support of the transaction, particular whether there are considerations common to other types of accepted structured-finance arrangements, whether those affected by the structure (such as Dutch regulators and counterparties to these transactions) can endorse the arguments as reasonable in light of their own interests and values, and whether the arguments could be made publicly, to a well-informed audience, without a sense of embarrassment. The question is always whether a legal argument forms part of a larger-scale framework for interaction that

78 GEO. L.J. 281 (1989); William N. Eskridge, Jr., Dynamic Statutory Interpretation, 135 U. PA. L. REV. 1479 (1987); Frank H. Easterbrook, Statutes’ Domains, 50 U. CHI. L. REV. 533 (1983).

230 See Shayndi Raice \& Margot Patrick, The Rise of the "Stichting," an Obscure Takeover Defense, WALL St. J. (Apr. 22, 2015); see also Adam Cohen, “'Going Dutch’ Has New Meaning in Corporate Takeover Battles,” WALL ST. J. (May 22, 2006). Perhaps because poison-pill takeover defenses are not as sexy and newsworthy as alleged money laundering by heads of state around the world, there has been no massive document dump and investigative reporting on Dutch stichtings. Nevertheless, in theoretical terms the issues are similar, and of significant general importance. 
is grounded in reasons that can be shared by the political community as a whole. Focus for a moment not on the property of being shared by a political community, but specifically on some consideration being a reason. Reasons do not arise out of nothing - they acquire their intelligibility with respect to something, such as an agent's desires, beliefs about what conduces to a welllived life, preference for a certain state of affairs of the world, and the like. ${ }^{231}$ They serve to explain action and justify it to others, ${ }^{232}$ and to perform this role they must make sense with reference to some conception of value that can be shared by others. Legal reasons must be intelligible with respect to the sorts of values that support and justify a conclusion that it is permissible to do something. It may be too strong to assert that the law pertaining to some area - say, Dutch charitable foundations - has only one purpose. Old tools can be pressed into service to solve new problems, and entirely new tools may be invented by creative engineers. Synthetic leases, asset-backed securities, conservation easements, lawyer contingent fees, and countless other legal structures were once unknown, may have appeared very odd at first, and are now widely accepted. My claim is therefore not that stichtings must adhere to a charitable purpose and cannot be pressed into service as part of an anti-takeover defense. There must still be an overall sense of intelligibility about the application of the law to the problem, however, for it to be reasoned. For example, grasping that stichtings separate ownership and control, and that such separation may be useful in other contexts, is part of the reasoned explanation for the takeover defense.

Social values can change, innovation can be beneficial, and there is a role for lawyers in pushing the boundaries of what is currently considered acceptable. A legal-process account of ethical legal advising always risks sounding conservative, tied as it is to existing law. As the next section argues, however, existing law also contains the resources for its own further development, extension, and reform. The emphasis on a disciplined process of reason-giving actually enhances rather than inhibits the capacity of the law to evolve.

\section{JetTisoning LegAL-Process BAGGAGE}

On the legal-process story, the law represents an official settlement of "the problems of people who are living together in a condition of interdependence." ${ }^{233}$ Law-interpreters, whether lawyers (the subject of this Article) or judges (more frequently the concern of scholars), are presumed to

\footnotetext{
${ }^{231}$ See, e.g., NichOLAS RESCHER, INTRODUCTION TO VALUE THEORY (1969).

${ }^{232}$ Id. at 21.

${ }^{233}$ HART \& SACKS, supra note _, at 159.
} 
have the power of "reasoned elaboration" of the principles or policies comprising the official settlement, which are presumed to have some relationship with the purpose underlying the social arrangement in question. ${ }^{234}$ Reason is what differentiates a legitimate interpretation of a political community's law from the exercise of naked power by the state or a private actor. ${ }^{235}$ As modern editors of the Hart and Sacks materials have shown, this view was enormously influential during the middle of the Twentieth Century. ${ }^{236}$ It remains influential today. Substitute "official settlement” for "plan” and many elements of Scott Shapiro’s planning theory of law look a lot like Hart and Sacks's introductory notes on the function of law. ${ }^{237}$

The legal process school has always attracted heated criticism for its apparent conservativism and complacency. Calling for a reasoned elaboration of law implies that there are norms for the regulation and evaluation of an interpretation of law as reasonable. These norms have to be external to the law itself; otherwise a reasoned elaboration is simply a ratification of the status quo. ${ }^{238}$ Arguably the reputation of the legal process school never recovered from Herbert Wechsler's criticism of the Supreme Court's decision in Brown v. Board of Education as lawless, because not grounded in neutral principles - that is, not a reasoned elaboration of law. ${ }^{239}$ Segregation may be wrong as a matter of policy, Wechsler argued, but it is not wrong in principle. ${ }^{240}$ Segregation, and the Brown decision, both embody value choices. One of them is clearly right and the other wrong - Wechsler was not defending segregation on the merits - but Brown cannot be defended as an exercise in reasoned elaboration of law, he concluded. ${ }^{241}$ Wechsler may have simply done a bad job interpreting the reasoning underlying the Brown decision.

One can certainly give a reasoned elaboration of Brown that begins with the principle that the Fourteenth Amendment demands equality and

${ }^{234} \mathrm{Id}$. at 148.

${ }^{235}$ See Wechsler, supra note _, at 11-12.

${ }^{236}$ See William N. Eskridge, Jr. \& Philip P. Frickey, An Historical and Critical Introduction to The Legal Process, in HART \& SACKS, supra note —, at xcix - cvi.

${ }^{237}$ Compare SHAPIRO, supra note _ ; and HART \& SACKS, supra note _ , at 102-58.

${ }^{238}$ See Elizabeth Mensch, The History of Mainstream Legal Thought, in THE POLITICS OF LAW 13, 29 (David Kairys ed., rev'd ed., 1990).

239 See Neil Duxbury, Faith in Reason: The Process Tradition in American Jurisprudence, 15 CARDOZO L. REV. 601, 674-77 (1993).

${ }^{240}$ See Wechsler, supra note _, at 32-33.

${ }^{241} I d$. at $19-20$. 
segregation violates equality. ${ }^{242}$ The NAACP Legal Defense Fund lawyers' strategy was precisely to demonstrate that an immanent constitutional equality value was already present in Court decisions involving segregation in higher education, for example. But the critique of Wechsler's argument, and of legal process theory generally, goes deeper than that. Wechsler contended that the Brown decision lacked legitimacy because a court would lack democratic legitimacy if it made decisions in a non-neutral, pollical, ideological, or value-laden manner. Criticism of judicial review for engaging in policymaking assumes that deference to legislative decisions is warranted because legislatures are democratically legitimate. If legislatures themselves lack democratic legitimacy, however, there is no reason to defer to their decisions. ${ }^{243}$ In other words, Wechsler's critique of Brown depended on a confidence that neutral, apolitical decisionmaking was possible somewhere, and trust in legislatures "rested on the judgment that life in American society was open and free enough to be called 'democratic." 244 The societal inequalities underlying Brown were obvious, even then. Decisions to maintain systems of supposedly separate but equal public schools were made by all-white legislatures, whose members were chosen by all-white electorates.

This critique may be sharpened by returning to the political-moral foundations of the legal process account. This theory relies heavily on the Rawlsian idea that giving and evaluating legal reasons is always "from the point of view of citizens in the culture of civil society." 245 The difficulty with this is, white and black citizens of Southern states around the time of the Brown decision were almost literally inhabiting different societies. The liberal political theory of Rawls asks citizens, recognizing each other as free and equal, to propose political terms on which they are prepared to live with each other. ${ }^{246}$ The terms proposed by white Southerners, in general, were to live with black Southerners only in a relationship of domination. These terms clearly fail the test of what others might reasonable accept as fair terms of social cooperation. ${ }^{247}$ A similar point could be made with respect to all-male legislatures and other political institutions prior to the extension of the right of suffrage to women. Other sources of inequality based on existing and accepted principles of social cooperation may not be as obvious, however.

${ }^{242}$ Charles L. Black, Jr., The Lawfulness of the Segregation Decisions, 69 YALE L.J. 421, 428 (1960).

${ }^{243}$ Peller, supra note _, at 611.

${ }^{244} I d$. at 614 .

${ }^{245}$ Rawls, supra note _, at 382.

${ }^{246} \mathrm{Id}$. at 392.

${ }^{247} \mathrm{Id}$. at 395. 
Huge sums of money are spent influencing the content of legislation and judicial decisions, from direct contributions to candidates, to funding of "dark money" organizations that spend on campaigns to influence elections, to lobbying members of Congress, to endowing think tanks and other institutes that pump out position papers, editorials, and other efforts to change the terms of public debate. It should not be surprising when the social framework for cooperation is systematically biased in favor of the wealthiest individuals and corporations. If the only reasons that counts in legal advising are those that are part of existing law, then legal discourse itself will tend to ratify existing maldistributions of wealth and power in society.

I am not a romantic about the political process, but I am a bit of an optimist about law. There are mechanisms within the law for challenging unjust hierarchies and distributions of resources. Consider the legal obstacles the Trump administration has faced to the implementation of (allegedly) invidiously discriminatory travel ban orders that had been drafted and put into place without careful attention to the disciplined process of reasoning. ${ }^{248}$ The response by the judiciary to these executive orders was surprising to many observers knowledgeable about immigration and national security law. On the law as it existed at the time the executive orders were issued, it appeared fairly clear that the President had the statutory authority to issue the orders and that reviewing courts would not second-guess a facially legitimate reason for the action. The Immigration and Nationality Act includes a very broad statutory delegation of authority to the President to prohibit the entry of any alien or class of aliens into the United States:

Whenever the President finds that the entry of any aliens or of any class of aliens into the United States would be detrimental to the interests of the United States, he may by proclamation, and for such period as he shall deem necessary, suspend the entry of all aliens or any class of aliens as immigrants or nonimmigrants, or impose on the entry of aliens any restrictions he may deem to be appropriate. ${ }^{249}$

While the President's power is of course limited by the Constitution, and the President's action may not infringe on fundamental rights, courts have been extremely reluctant to second-guess a determination by the President that is justified on its face. The Supreme Court has said that it would not look behind a "facially legitimate and bona fide" reason for denying entry into the

248 See Washington v. Trump, 853 F.3d 933 (9th Cir. 2017); International Refugee Assistance Project v. Trump, 857 F.3d 554 (4th Cir. 2017).

2498 U.S.C. § 1182(f). 
U.S. ${ }^{250}$ The Court reaffirmed the "facially legitimate and bona fide" standard quite recently, in Kerry v. Din. ${ }^{251}$ Justice Kennedy's concurrence, which is the controlling opinion in that case, stated that

Once this standard [from Kleindienst] is met, courts will neither look behind the exercise of that discretion, nor test it by balancing its justification against the constitutional interests of citizens the visa denial might implicate. This reasoning has particular force in the area of national security, for which Congress has provided specific statutory directions pertaining to visa applications by noncitizens who seek entry to this country. $^{252}$

The Kleindienst test works in conjunction with the general principle that courts should not engage in "judicial psychoanalysis" to determine the "real" motivations behind a government official's actions. ${ }^{253}$ Given these deferential standards of review and its grounding in a broad express grant of statutory authority, Trump's executive orders ordinarily would be entitled to a very strong “presumption of regularity” by the judiciary. ${ }^{254}$ This has not proven to be the case. Significantly, in light of the claims in this Article about the formal characteristics of legality, the Fourth Circuit opinion on the travel ban order specifically addresses the insincere, pretextual nature of the national security justification, given the likely true motivation of anti-Muslim discrimination. ${ }^{255}$ The response by the legal profession and the courts has reminded all of us that an insistence on principled decisionmaking and reasonable elaboration of law can be a significant stabilizing force in an otherwise unruly democracy.

Another criticism of a political and process-focused account of legal advising is that it detaches lawyers from the resources of ordinary morality, isolating them in an amoral, technocratic domain. ${ }^{256}$ In extreme cases, it establishes a role-differentiated scheme of duties that threatens the moral agency of people who occupy these social roles. A widely shared conception of moral agency holds that one is responsible for one's intentional actions

\footnotetext{
${ }^{250}$ Kleindiest v. Mandel, 408 U. S. 753 (1972).

251135 S. Ct. 2128 (2015).

${ }^{252} \mathrm{Id}$. at 2140 (Kennedy, J., concurring) (internal quotations and citations omitted).

253 McCreary County v. ACLU, 545 U.S. 844, 862, (2005).

254 See United States v. Chem. Found., Inc., 272 U.S. 1, 14-15 (1926).

255 International Refugee Assistance Project v. Trump, 857 F.3d 554, 591-92 (4th Cir.

256 See, e.g., Postema, supra note _; Thomas Nagel, Ruthlessness in Public Life, in MORTAL QUESTIONS 75 (1979).
} 2017). 
taken with knowledge of their reasonable foreseeable effects. ${ }^{257}$ The usual way of bringing home the force of this objection is to imagine either a grossly unjust legal system or an aberrational law or legal practice. Alasdair MacIntyre's argument that social institutions threaten moral agency begins with the parable of $J$, for jemand (Everyman), who spends his career scheduling passenger and freight trains, but never bothering much to find out what cargo is being carried by the trains - "a habit that endured through a later period, when the freight consisted in munitions and the passengers were Jews on their way to extermination camps." 258 The possibility that Everyman is Eichmann is part of a long tradition of using Nazi laws to test theories of the concept of law, the obligation to obey the law, and the role ethics of lawyers and judges. ${ }^{259}$ The case of the Fugitive Slave Law in the antebellum United States is also a fixture of the jurisprudence literature. ${ }^{260}$ In the case of widespread injustice in the legal system, as in a tyrannical government like the Nazi regime in Germany, one can readily see why the Nuremberg defense of "just following orders" affords no justification for engaging in moral wrongdoing. The system onto which professionals seek to offload moral responsibility is itself pervasively wicked. Similarly, the Fugitive Slave Law is so glaringly unjust that it raises psychological rather than normative issues - what is it that makes professionals more likely to go along with wrongdoing that, in retrospect, is so patent? ${ }^{261}$

A different type of example - likely more controversial - involves an end that is just, such as safeguarding national security, but means that violate some of the basic constraints inherent in the concept of legality. For example, the initial lack of fair procedures for classifying detainees at the U.S. military detention facility at Guantánamo Bay, Cuba, as unlawful combatants, and the subsequent procedural deficiencies in the Combatant Status Review Tribunals created by the government, fail to satisfy most generally agreedupon criteria of the rule of law, such as openness, non-retroactivity, and generality. ${ }^{262}$ Lawyers disagree about the requirements of professional ethics

${ }^{257}$ See Alasdair MacIntyre, Social Structures and Their Threat to Moral Agency, 74 PHIL. 311 (1999).

${ }^{258}$ MacIntyre, supra note _, at 312.

${ }^{259}$ Richard H. WeIsSBerg, Vichy LaW AND the Holocaust in France (2013); INGO Muller, Hitler's Justice: The COURTS OF THE ThiRD Reich (1992); Lon L. Fuller, Positivism and Fidelity to Law: A Reply to Professor Hart, 71 HARV. L. REV. 630 (1958).

${ }^{260}$ See, e.g., Mark C. Murphy, Natural LaW in Jurisprudence and Politics (2006).

${ }^{261}$ See, e.g., David Luban, The Ethics of Wrongful Obedience, in LEGAL ETHICS AND HUMAN DigNITY (2007).

${ }^{262}$ See generally Clive STAFFORD SMITH, EIGHT O’CLOCK FERRY TO THE WiNDWARD SidE: SEEKING JUSTICE IN GUANTÁNAMO BAy (2007); JOSEPH MARGULIES, GUANTÁNAMO 
in areas of procedural injustice within a basically just legal system; some work within the relatively lawless regime to seek to obtain the best result for clients, while others avoid entanglement with procedures they liken to a kangaroo court, concerned that their participation will help legitimate the process in the eyes of the public. ${ }^{263}$

The moral agency critique is a serious one, but it is not an issue only for legal-process focused accounts of legal advising. Any claim that a social role carries with it a distinctive set of obligations is subject to the objection that the role, and the actions it prescribes, stand in need of justification in moral terms. ${ }^{264}$ One way to provide this justification, on an analogy with ruleconsequentialism, is to give a justification in moral terms of a set of institutions and practices with constitutive rules that regulate actions within the practice, but preclude resort back to the considerations that justified the practice as a whole. ${ }^{265} \mathrm{~A}$ variation on this method is to permit occupants of a social or professional role to have recourse back to the underlying considerations justifying the role, if it appears that departing from the obligations characteristic of the role is the best way to remain faithful to the ends of the role. ${ }^{266}$ Outside of a comprehensively unjust system, or a locally dysfunctional regime such as the early iterations of the military tribunals at Guantánamo, the institutions of the law and legal system, and associated roles and practices, are justifiable on the grounds given Section III.A. That is, the law provides a means for giving public reasons in justification of actions that affect the interests of others, when ordinary, non-institutional justifications would fail to account for moral pluralism and reasonable disagreement. The law does not work only by compulsion or terror, as Hobbes contended, but by furnishing a principled discourse in the first-person plural, from the point of view of the political community as a whole. It does not purport to disable entirely the moral agents of citizens and their legal advisors. If a lawyer finds herself in the position of MacIntyre's $J$, then a range of options is available,

AND THE Abuse of PREsidential POWER (2006); David Luban, Lawfare and Legal Ethics in Guantánamo, 60 STAN. L. REV. 1981 (2008).

263 See Alexandra D. Lahav, Portraits of Resistance: Lawyer Responses to Unjust Proceedings, 57 UCLA L. REV. 725 (2010).

264 See APPlBaum, supra note _; DAVID LUBAN, LAWYERS AND JUSTICE 130-33 (1988); Alan H. Goldman, The Moral Foundations of Professional Ethics (1980); Michael Hardimon, Role Obligations, 91 J. PHIL. 333 (1994).

265 See, e.g., DARE, supra note _, at 44-46; John Rawls, Two Concepts of Rules, 64 PHIL. REV. 3 (1955)); T.M. Scanlon, Rights, Goals, and Fairness, in CONSEQUENTIALISM AND ITS CRITICS 74 (Samuel Scheffler ed. 1988).

266 See Mortimer H. KADISH \& SANFORD H. KADISH, Discretion TO DisObeY: A STUDY OF LAWFUL DEPARTURES FROM LEGAL RULES (1973) (giving a well-known defense of recourse roles); see also Postema, supra note _ , at 82-83 (employing the concept of recourse roles in legal ethics). 
including whistleblowing, civil disobedience, conscientious objection, or simply finding another job. ${ }^{267}$

It is important to emphasize, however, that these responses depend on a conclusion that there is something deeply and fundamentally unjust about the system itself, not that one's client has a project with which one disagrees in moral terms. It is part of the burdens of judgment in a liberal political community to recognize the existence of a wide range of reasonable moral beliefs, whether religiously or secularly based. ${ }^{268}$ Opting out of the discourse of legal reason-giving ought to be an extraordinary remedy. As the examples of Brown v. Board of Education and the legal responses to President Trump's travel ban orders show, however, staying within the discourse of law provides resources for rectifying legal injustice. Segregation and a "Muslim ban" are not only morally wrongful, but they violate political commitments of a liberal community under the rule of law. Resorting too quickly to extra-legal critical standpoints risks undermining the capacity of the legal system to respond to injustice.

\section{CONCLUSION}

One of the motivations behind the long-running debate between positivism and natural law is the belief that law should make some difference to what citizens of a political community have reason to do, or refrain from doing. The normativity of law that is, by nature, determined by social facts thus becomes a bit mysterious, creating a challenge for positivists. Greenberg's moral impact theory asserts that law merely summarizes what we already have reason to do; law does not change our normative situation, but clarifies it. Shapiro's planning theory is closer to what I have defended here, in that it focuses on the value to a political community of having a means to resolve disagreement and settle on a coordinated plan of action. This Article proposes going beyond any theory of law as such, and focusing on the value of legality as a practice of reason-giving - specifically, of giving reasons from the political standpoint, to other free and equal citizens, in terms they can reasonably accept. It also focuses not so much on legal normativity but on the ethical demand for a reasoned justification for a conclusion that the law permits or requires some action. With respect to any issue of even moderate complexity, citizens are unlikely to be able to fully access and employ the technical apparatus of law. Expert legal advisors therefore play an essential role in the maintenance of the rule of law in a liberal community,

267 See WENDEL, supra note _, $\S 6.3$ at 115-20 (considering options of civil disobedience and conscientious objection for lawyers).

${ }^{268}$ See RAWLS, supra note _, at 53-57 (discussing the burdens of judgment). 
by reasoning in good faith about what the community's law permits. What might sometimes seem like a relatively marginal intellectual discipline - legal ethics - is in fact central to a valuable social practice that manifests respect for the dignity of all members of a political community. 